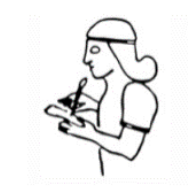

\begin{tabular}{|l|l|l|l|}
\hline ARCHIVUM ANATOLICUM (ArAn) & $15 / 2$ & 2021 & $431-463$ \\
\hline
\end{tabular}

\title{
ANTIKK KAYNAKLARDA İSKELET KIRIK VE ÇIKIKLARININ TEDAVİ YAKLAŞIMI
}

Gülseren MUTLU*

\section{Makale Bilgisi}

Başvuru: 26 Ekim 2021

Kabul: 24 Kasim 2021
Article Info

Received: October 26, 2021

Accepted: November 24, 2021

Makale Türü: Araştırma Makalesi

$\ddot{O} z$

Insanlığın hayatını devam ettirebilmek için yaptığı ilk buluşlar, aynı zamanda ilk bilimsel çalışmaların kökenini oluşturmaktadır. Antik Çă̆ Yunan ve Romalı doktorların, kırık ve çıkığa bağlı deformitelerin azaltılması için birçok ilginç düzenek oluşturmaları ve oluşan travmaları yerinde sabitlemek için atel, bandaj ve ped uygulamaları bugüne değin korunmuş olan klasik tıp uygulamalarındaki başarıya öncülük etmiştir. Antik Çağ'da dar ve kısıtll imkanlarla daha çok, hastanın takibi ve ilaçla tedavi esasına dayanan konservatif tedavi yaklaşımı tercih edilmiştir. Açık ve kapalı kırık vakaların tedavisi için hazırlanan ilaçlar, farmasötik alandaki uygulamaları yansıtması bakımından ayrıca önemlidir.

Antik Çă̆ kırık ve çıkıkları hakkında en ayrıntılı bilgiyi ise Hippokrates, Celsus ve Galenos aktarmıştır. Hippokrates'in eserinde aktarlan kırık kemiklerin doğru yerine oturtulamadı̆̆ ya da dışarıya çıktığı durumlarda kemiğin kesilip çıkartılması (rezeksiyon) işlemi, Antik Çă̆ kırık tedavisinde cerrahi tedavi yaklaşımına örnek oluşturmaktadır. Bugün modern tıbbın gelişimi ile iskelet sistemi kırık ve çıkıklarının tedavisi cerrahi yöntemlerle çok daha ileri seviyelere taşınmış olmasına rağmen, bazı durumlarda konservatif tedavi yaklaşımı halen işlevsel olarak kullanılmaya devam etmektedir.

Çalışmamı esas olarak Anadolu toplumundan verilen örneklerle Antik Çă̆ kırık ve çıkıkların iyileştirilmesinde kullanılan yaklaşım ve yöntemlerin, bugün halen kullanilmakta olan konservatif tedavi yöntemlerinin kökenine işaret etmesine vurgu yapmayı amaçlamaktadır. Bu amaçla çalışma,

* Dr. Öğr. Üyesi, Pamukkale Üniversitesi, Fen Edebiyat Fakültesi, Tarih Bölümü, Eskiçağ Tarihi ABD. gmutlu@ pau.edu.tr; ORCID: 0000-0001-7434-2036.

$\mathrm{Bu}$ çalışmanın oluşmasında sağlamış olduğu katkılardan dolayı Fiziksel Tıp ve Rehabilitasyon Uz. Dr. Mehmet B. Türkmen'e teşekkür ederim. 
antik yazarların aktardıkları bilgiler çerçevesinde ve onları destekleyen Arkeometri Sonuçları ve Arkeolojik Raporlar ile modern tıp uygulamalarının karşılaştırmalı değerlendirmesinden oluşmaktadır.

Anahtar Kelimeler: Antik Çă̆, Yunan, Roma, kırıklar, çıkklar, tedavi.

Treatment Approach to Skeletal Fractures and Dislocations in Ancient Resources

\section{Abstract}

The first inventions made by humans in order to continue their lives also constitute the origin of the first scientific studies. Ancient Greek and Roman doctors created many interesting mechanisms to reduce deformities due to fractures and dislocations; and the use of splints, bandages and pads to fix traumas in place have been leading successes in classical medicine practice and preserved until today. In ancient times, despite limited opportunities, conservative treatment approach based on patient follow-up and drug treatment has been mainly preferred. Drugs prepared for the treatment of open and closed fracture are particularly important since it reflects the applications in the pharmaceutical field.

The most detailed information on fractures and dislocations of ancient times can be found in their seminal works of Hippocrates, Celsus and Galenos. As described by Hippocrates, the process of cutting and removing the bone (resection) in cases, where the broken bones cannot be properly placed or protruded, has been an example to the surgical treatment approach in the fracture treatment of ancient times. As of today, due to the development of modern medicine, the treatment of skeletal system fractures and dislocations has been improved to a great extent through surgical methods. However in some cases, the conservative treatment approach has been still applied functionally.

Our study aims to emphasize that the approaches and methods applied in the treatment of fractures and dislocations of ancient times, with examples given from the Anatolian society, point out to the origin of conservative treatment methods that is still applicable today. For this purpose, the study consists of a comparative evaluation of modern medicine practices and Archaeometric Results and Archaeological Reports supporting the respective works of the ancient authors.

Keywords: Ancient, Greek, Roman, fractures, dislocations, treatment.

\section{GÍRİş}

İskelette kemiğin kısmen ya da tamamen kırılması, kemiğin yapısında meydana gelen değişimler ve eklemin yerinden çıkması ya da yer değiştirmesi şeklindeki travmatik durumlar, bir toplumun çevreyle olan ilişkilerini, kültürünü belirlemede en önemli unsurlardan birini oluşturmaktadır ${ }^{1}$. Birçok faktörden kaynaklanan ve dışsal bir etki ile

1 Donald J. Ortner ve Walter G. J. Putschar, Identification of Pathological Conditions Human Skeletal Remains, (Wahington: Smithsonian Institution Press, 1981), 72-74. 
oluştuğu bilinen travmatik olayların görülme sıklığı ve vücuttaki yeri, yine büyük ölçüde o toplumun kültüründe etkili olmuştur. Taşla, sobayla, kılıçla yaralanmalar tarihi süreçte çeşitli travmalarla daha da çeşitlenmiştir.

Prehistorik dönemde oldukça karışık olan kemik kırıklarının tedavisi, çoğunlukla ahşaptan veya deriden atellerle bağlanarak yapılmıştır. Antik Mısır'da (MÖ 2750-2625), kırık kemiklerin etrafina sarılan ateller (şekil 1), ilk cerrahi uygulamaları oluşturmaktadır. Bilinen en eski cerrahi metin olan Edwin Smith Papirüsü (MÖ 1600) vücudun baştan ayaklara çeşitli bölgelerinde oluşan travma ve kırık vakalarını kafatası, yüz, burun, çene, üst kol, kaburgalar, omuz ve omurga şeklinde gruplandırarak aktarmıştır ${ }^{2}$. Papirüs'te keten, ketenle sarılan ahşap ve sert post benzeri ketenler olmak üzere üç tür atelden söz edilmiştir³. Muhtemelen kırılan kemikler bir ahşap vasıtasıyla bandajlanarak sabitlendiği düşünülmüş olup hurma ağacının liflerinden yapılan ateller bu amaçla ilk uygulanan yöntemlerdendir. Edwin Smith Papirüsü'nde yüzden fazla ön kol kırığının bu atellerle sabitlendiği ve bandajlama işleminde yağ, bal, keten ve tiftik gibi maddeler kullanıldığ anlatılmışıır'. Ayrıca Papirüs'de tedavi amacıyla yapılan pansuman işlemi ve tarihte ilk kez tarif edilen suturdan (dikiş) bahsedilmiştir5.
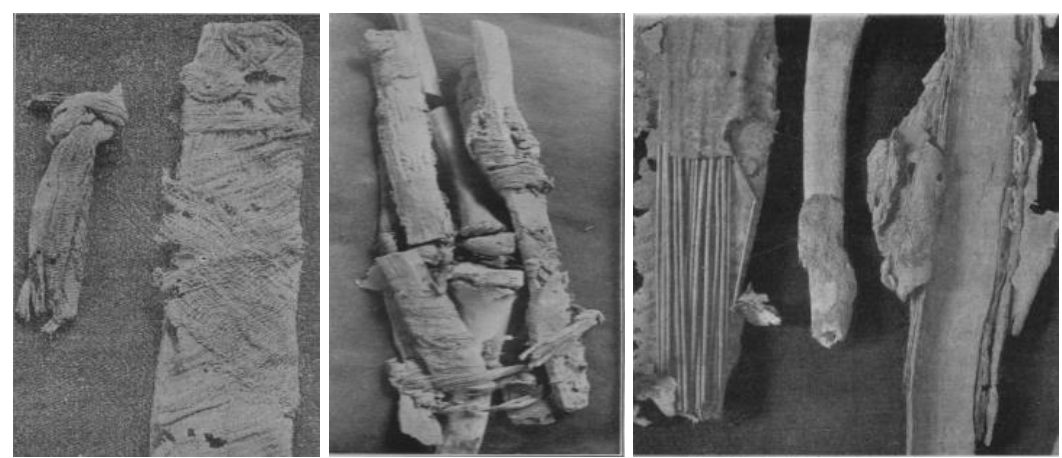

Şekil 1. Misır'da kirık kemiklerin tedavisinde kullanılan atel ve bandaj. (Smith 1908, 733-735)

2 Stig Brorson, "Management of Fractures of the Humerus in Ancient Egypt, Greece, and Rome: AnHistorical Review", Clinical Orthopaedics and Related Research, 467/7, (2009), 1907-1910; Susan Standring, "A brief history of topographical anatomy”, Journal of Anatomy, 229, (2016), 32; Chauncey D. Leake, The Old Egyptian Medical Papyri, (Laweance: University of Kansas Press, 1952), 11.

3 Mehryar Mashouf, "The Edwin Smith Surgical Papyrus”, Ed. Nil Sarı, A. H. Bayat, Y. Ülman ve M. Işın, 38. Uluslararası Tıp Tarihi Kongresi Bildiri Kitabı I, (Ankara: TTK Yayınları, 2005), 27.

4 James Henry Breasted, The Edwin Smith Surgical Papyrus, Vol I, (Chicago, Illinois: The University of Chicago Press, 1930), 56-360; G. E. Smith, "The Most Ancient Splints", British Medical Journal I, 28, (1908), 732-734.

5 Mehryar Mashouf, "The Edwin Smith Surgical Papyrus”, 27. 
Hearts Papirüsü'nde (MÖ 1500) kırık ve çıkıkların tedavisinde günümüz alçı uygulamasını anımsatan, un ve bal karışımına bulanmış sargı bezleri ile kırılan kemiklerin sabitlenip kurumaya bırakılarak sertleşmesi işlemi anlatılmıştır. Benzer reçinelerin Yunan Roma tıbbında uygulandığ 1 görülmektedir ${ }^{6}$. Tarihsel süreçte doğada alçı taşı olarak bulunan kalsiyum sülfat, sert fiber ve yumuşak fiber alçı alternatifleri kırıkların tespitinde halen kullanılmaktadır ${ }^{7}$. İnsanoğlunun doğadaki çeşitli maddeleri tarihsel süreçte ihtiyaçları doğrultusunda kullanarak çeşitli tedavi metotları ve ilaçları deneme yanılma yöntemi ile geliştirdikleri anlaşılmaktadır.

Antik Çağ kırık ve çıkıklar konusunda en ayrıntılı bilgiyi Hippokrates (MÖ 480- MÖ 370), De Fracturis ve De Articulis, Celsus (MÖ 25- MS 50) De Medicina ve Galenos (MS 129-216) Methodus Medendi isimli eserleriyle aktarmıştır. Hippokrates'in eserleri, özellikle kemikler ve bağlantılı dokular üzerinedir. Bunlar anatomisi en iyi bilinen bölgelerdir. Hippokrates, anatominin klinik uygulamanın bir parçası olduğunu kabul etmiş ve ampirik tıp uygulamaları ile tapınak uykusuna yatırılan hastalarda, insan vücudunun anatomisini daha yakından tanımıştır. Celsus eserinde, kafatasından başlayıp burun, çene ve ekstremite kemiklerini ayrıntılı olarak tanımlamış, farklı kırık modellerini ve bunların tedavi yöntemlerini açıklamıştır. Ayrıca Celsus, Hippokrates'e yakın bir anlayışla ekstremitelerin kırık ve çıkıklarının yerine konması için ekstansiyonkontrekstansiyon $^{8}$ işlemleri uygulamış ve bandajlamaya özel önem vermiştir?.

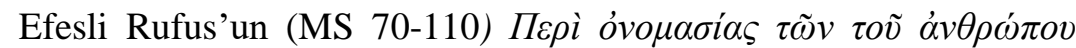

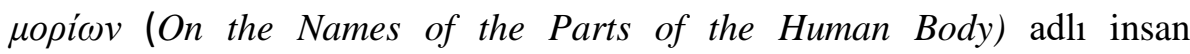
vücudunun kısımlarını isimlendiren anatomi kitabı ise, kırık ve çıkıkların tanı ve tedavisinde el kitabı niteliğinde bir eserdir ${ }^{10}$. Soranus/Soranos (MS 98-138), De Signis Fracturarum adlı eserinin ilk dokuz bölümünde kafatası kırık tiplerini, on birinci bölümden itibarense burundan ayağa kadar olan kırıkların belirtilerini ele almıştır.

6 Ali Haydar Bayat, Tip Tarihi, (İstanbul: Merkezefendi Geleneksel Tıp Derneği Yayınları, 2010), 64.

7 Philippe Hernigou, "Plaster of Paris: the orthopaedic surgeon heritage", Orthopaedic Heritage, 40, (2016), 1767-1778; Bülent Dağlar, "Ortopedi ve travmatolojide alçı", TOTBID (Türk Ortopedi ve Travmatoloji Birliği Derneği) Dergisi, 17, (2018), 259-261.

8 Ekstansiyon: gerilme ve eklem açısının büyümesi; kontekstansiyon: kırıklarda kemik uçlarını karşı karşıya getirmek amacıyla uç kısımdan dışarı doğru çekme işlemidir.

9 Hippok. De Fracturis, I.

10 Maria Bujalkova, "Rufus of Ephesus and his contribution to the devalopment of anotomical nomenclature", AMHA-Acta Medico Historica Adriatica, 9/1, (2011), 89-92. 
Arkeolojik verilerden Anadolu'da Erken Roma Dönemi'ne tarihlenen Niğde ili Çiftlik ilçesinde bir iskeletin radius kemiğinde ve ulnasında iyileşmiş kemik kırıkları tespit edilmiştir. Yine aynı iskeletin kaburgasında iyileşmiş kırıklar olduğu saptanmıştır ${ }^{11}$. Karia bölgesinin önemli bir yerleşim yeri olan Stratonikeia'da ise Hellenistik Roma Dönemi'ne ait erişkin bir erkek iskeletinin sol 5. Metatarsalinin travma sonucu oluşan kırıkta yanlış bir kaynaşmanın olduğu tespit edilmiştir ${ }^{12}$. Bölgenin coğrafi dağlık yapısı göz önünde bulundurularak travmaların düşme gibi doğal nedenlerle oluşmuş olabileceği düşünülen arkeolojik raporlarda iskeletlerin patolojik incelemelerinin sonucunda, istisnai durumlar bulunmakla birlikte çoğunlukla kemiklerde yanlış kaynaşmanın tespit edilememiş olması, dönem şartları düşünüldüğünde doğru bir tedavi yaklaşımının benimsenmiş olabileceğini akla getirmektedir.

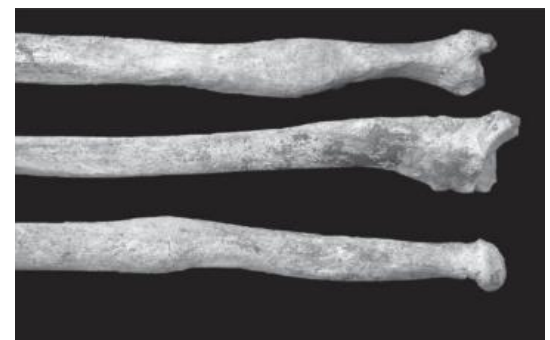

Şekil 1. Radius ve ulnada (ön kol kemikleri) iyileşmiş kemik kırıkları. (XXIV. Arkeometri Sonuçları)

\section{KIRIKLAR}

Travmalar sonucunda kemiğin anatomik bütünlüğünün bozulmasına kırık denir. Kırıkların iyileşme mekanizması üzerine son yıllarda yapılan çalışmalar oldukça ilgi uyandırıcıdır. Hastanın genel muayenesi, belirtiler açısından değerlendirilmesi ve hastadan alınan anamnez, tıpkı bugün olduğu gibi Antik Çağ'da da oldukça önem verilen bir husus olmuştur. Celsus, kırılan kemikte parçalar temas halinde olduğunda, hareket esnasında ses geleceği ve bıçak saplanması acısı hissedileceğini bildirmiştir. Ancak eğik temas söz konusu olduğunda parçalar yerinde olmayacağından kırık uzvun

11 Ali Metin Büyükkarakaya, Yılmaz Selim Erdal ve Metin Özbek, "Tepecik/Çiftlik İnsanlarının Antropolojik Açıdan Değerlendirilmesi”, XXIV. Arkeometri Sonuçlar Toplantısı, (Ankara: T C Kültür ve Turizm Bakanlığı Kültür Varlıkları ve Müzeler Genel Müdürlüğü Yayınları, 26-30 Mayıs 2008) 126-127.

12 Mehmet Sağır, İsmail Özer, Zehra Satar, Erksin Savaş Güleç, "Stratonikeia İskeletlerinin Paleoantropolojik Analizi”, XXVIII. Arkeometri Sonuçları Toplantısı, (Çorum: T C Kültür ve Turizm Bakanlığı Kültür Varlıkları ve Müzeler Genel Müdürlüğü Yayınları, 28 Mayıs1 Haziran 2012), 62. 
diğerinden daha kısa görüneceğini açıklamıştır ${ }^{13}$. Hippokrates’te yine, kol kırıklarında iki ekstremite arasında uzunluk farkının bariz şekilde gözlemlenmemesine rağmen, uyluk kırıklarında aşırı kas kasılmasına bağlı olarak kısalık görülebileceğinden söz etmiştir ${ }^{14}$. Nitekim bugün travma şikayeti ile gelen hastaların değerlendirilmesinde, tanısal doğruluk bakımından radyografik görüntüleme yöntemleri tercih edilse de klinik muayenenin rolü yadsınamaz ${ }^{15}$. Bazı travma vakalarında örneğin kafa travmalı hastalarda bilinç bozukluğu, iletişim problemleri gibi sebeplerle anamnez ve fizik muayene sonucunda net bir değerlendirmenin yapılabilmesi mümkün olamamakla birlikte Antik Çağ'da olduğu gibi modern tıp için de alternatif yöntemlerin yanı sıra ilk olarak hastadan öykü (anamnez) alınması ve fizik muayenenin rolünün oldukça önemli olduğu anlaşılmaktadır.

\subsection{Ekstremite Kırıkları}

Celsus, kemik kırıklarını başlıca; enine kırıklar, eğik kırıklar ve kemik uçlarını bazen kör, bazen keskin olduğu durumlar şeklinde sınıflandırmış, bunlar içerisinde en kötü olanın, üçüncü yani kemik uçlarında oluşan deformasyon vakalarının olduğu kırıklar şeklinde bildirmiştir ${ }^{16}$.

Celsus kollar, önkol, uyluk, bacaklar ve parmak kemiklerinde oluşan kırıklarda ortak bir tedavi yaklaşımı öngörmüştür. En basit tedavinin enine kırıklarda olduğu, çoklu ve eğik kırıkların tedavisinin ise daha kötü olduğunu ifade etmiştir ${ }^{17}$. Soranus'ta Celsus'a yakın bir anlayışla, kemiğin ortası kırıldığında tehlikenin daha az, üst veya alt ekleme daha yakın bir noktada kırık gerçekleşmişse tedavinin daha zor olacağını ve acının daha çok hissedileceğini bildirmiştir ${ }^{18}$. Modern tıpta bugün tüm kırıklarda kırığın lokalizasyonu oldukça önemlidir. Kırık oluşan eklemin (eklem içi, eklem dış1) stabil olup olmaması, kırığın şekli (spiral, parçalı, transvers vd.), uzuvlarda kısalma ve kırığın oluştuğu bölgede yumuşak dokunun açık veya kapalı olması gibi etkenler tedavide değerlendirilmektedir. Örneğin; el

13 Cels. De Medicina. VIII. 10.

14 Hippokr. De Fracturis, XVIII.

15 Nikita Joshi, Alena Lira, Ninfa Mehta, Lorenzo Paledino, Richard Sinert, "Diognostic Accuracy, Physical Examination, and Bedside Ultrasound for Diagnosis of Extremity Fractures in the Emergency Department: A Systematic Review”, Academic Emergency Medicine, 20/1, (2013), 1-15.

16 Cels. De Medicina. VIII. 7.

17 Cels. De Medicina. VIII. 10.

18 Cels. De Medicina. VIII. 10; Çağatay Aşkit, "Soranus’Tex "On Signs of Fractures", Archivum Anatolicum 12/2, (2018), 22. 
kırıklarının tedavisinde kırığın ekleme yakın oluşması durumunun kombine birçok soruna yol açabileceği bilinmektedir ${ }^{19}$.

Celsus, bunların dışında ezilen ya da parçalanan, elmacık kemiği, kürek kemiği, kaburga, omurga, kalça, ayak bileği, topuk kemiği gibi hareketsiz kemiklerin kırıklarında da tedavi yaklaşımının benzer şekilde yapıldığını ancak açık yara durumunda, ona yönelik tedavinin uygulanması gerektiğini bildirmiştir ${ }^{20}$. Soranus ise Celsus'tan biraz farklı olarak kırıkları şekillerine göre ayırırken "parçalanmış, un ufak olmuş vb. adlar verilerek sınıflandırmıştır"'21. Modern tıpta üst bacak (femur) kırıklarının sınıflandırılmasında parçalı kırık, çok parçalı kırık vd. şeklinde yapılırken tedavisi protokolü de ona göre değerlendirilmektedir ${ }^{22}$.

Hippokrates, De Fracturis adlı eserinde ayrıntıları ile tarif edilen redüksiyon modunun yorumlanarak resmedildiği humerus kırı̆̆ 1 tedavisinde (Şekil 2); hasta koltuk altından asılı vaziyette zor oturur pozisyonda yüksek bir tabureye oturtulmuş, hastanın dirseğinden bir askı yardımıyla ağırlık asılmıştır. Hekim kırığı manuel olarak düzelterek keten bandajlama ile sabitleme işlemi yapmıştır ${ }^{23}$. Kırığın humerusta (üst kolda) olması durumunda Celsus, ekstansiyon işlemi yapılmamasını öngörmüştür ${ }^{24}$. Günümüz alt ekstremite kırıklarında özellikle güçlü kasların kırıkta yarattı̆ğ deplasman kuvvetini karşılayabilmek için traksiyon ${ }^{25}$ etkili bir yöntem olarak kullanılmaktadır ${ }^{26}$.

Hippokrates ekstremite kırıklarında çekme işleminin (traksiyon) özellikle iki güçlü adam tarafından yapılmasının önemli olduğuna vurgu yapmıştır ${ }^{27}$. Kapalı kırıklarda çekme işleminin (traksiyon) kuvvetli, açık

19 Sait Ada, Emin Bal, "El Kırıklarının Tedavisi”, TOTBID (Türk Ortopedi ve Travmatoloji Birliği Derneği) Dergisi, 3/1-2, (2004), 10-12; A. Mehmet Demirtaş ve Mahmut Kalem, "Erişkinlerde Önkol Kırıkları", TOTBID (Türk Ortopedi ve Travmatoloji Birliği Derneği) Dergisi, 7/1-2, (2008), 36-37.

20 Cels. De Medicina. VIII. 8.

21 Çağatay Aşkit, "Soranus'Tex "On Signs of Fractures”, 25-28.

22 Duman ve Ateş, "Femur Cisim Kırıkları", 1-2.

23 Hippokr. De Fracturis. VIII.; Brorson, "Management of Fractures of the Humerus in Ancient Egypt, Greece, and Rome: An Historical Review", 1910-1915.

24 Cels. De Medicina. VIII. 10.

25 Traksiyon: kemik ve kas bozukluklarında vücudun bir veya birkaç kısmına yapılan çekme kuvveti uygulamasıdır. Bkz. L. Newton Triggs, H. Pugh, J. Rogers ve A. Timms, "Key Musculoskeletal Interventions", Ed. S. Clarke-J. Tomlinson, Orthopaedic and Trauma Nursing, (2014), 80.

26 Alper Öztürk ve Önder Ersan, "Lower Extremity Skeletal Tractions", TOTBID (Türk Ortopedi ve Travmatoloji Derneği) Dergisi, 17, (2018), 327-330.

27 Hippokr. De Fracturis, XVIII. 
kırıklarda ise daha yumuşak yapılmasını önermiştir ${ }^{28}$. Nitekim traksiyon işlemi tarihsel süreçte kırıkların nihai tedavisinde kullanılmıştır. İskelet traksiyonu ortopedi alanında halen geçerliliğini koruyan etkili bir yöntemdir. Tabi ki doğru bir mekanizmanın oluşturulması bu işlemde iyi sonuçlar alınmasında etkili olacaktır.

Braun-Böhler splinti bu amaçla kullanılan bir mekanizmadır. BraunBöhler splinti, alt ekstremitede birçok bölgenin kırığında kullanılabilmesi gibi avantajları sebebiyle benzer yöntemler s1klıkla tercih edilmektedir. Yine 1911'de kullanılmaya başlanan Balkan Beam Frame, makara sistemi sayesinde istenilen traksiyon açısını gerçekleştirme için tercih edilen bir başka aparattır ${ }^{29}$. Günümüzde bu uygulamaların çoğunlukla lokal anaztezi altında, cerrahi olarak tespit edilemeyecek hastalarda ağrı kontrolünü sağlamak amacıyla kullanıldıkları bilinmekle birlikte temelde tedavi yaklaşımında traksiyon yöntemi esas alınmaktadır.

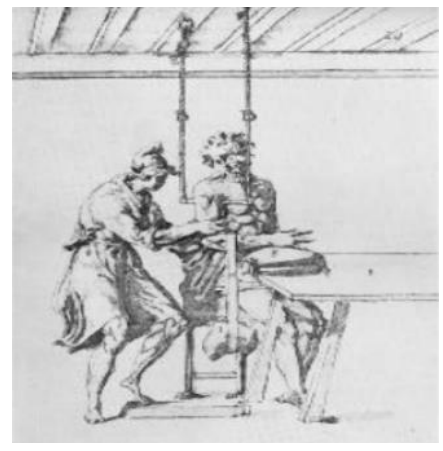

Şekil 2. Humerus (üst kol) kırıklarl için Hippokrates redüksiyon yorumlamasl. (Brors on 2009)

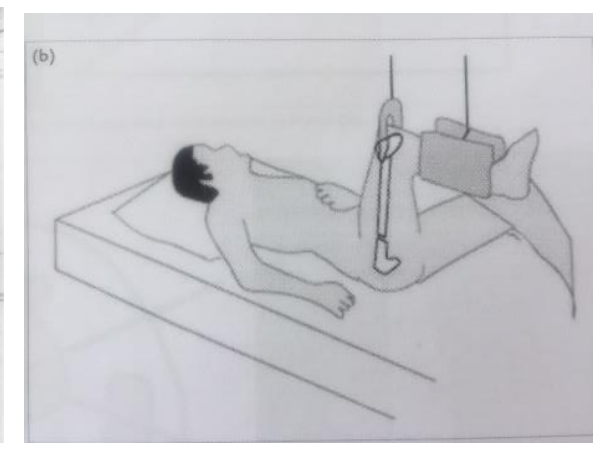

Şekil 3. Modern tıpta Subtrokanterik kirlkta traksiyon uygl. (Yavuz, vd. 2018)

\subsection{Atele alma, Alçı ve Bandajlama Uygulaması}

Galenos, iskelet sistemi hakkında geniş bilgilere sahip olan bir diğer Antik Çağ hekimidir. Humerus kemiğinin anatomik tanımını ayrıntı olarak yapmıştır ${ }^{30}$. Çarpılmış, kıvrılmış ve eğilmiş ekstremitelerin henüz yumuşakken, bir kalıba alınarak bağlanması ve düzeltilmesinin organın

28 Hippokr. De Fracturis, III.

29 İbrahim Alper Yavuz, Cahit Koçak ve Fuad Öken Özdamar, "İskelet Traksiyonunda Temel Prensipler”, TOTBID (Türk Ortopedi ve Travmatoloji Birliği Derneği) Dergisi, 17, (2018), 316-318.

30 Stig Brorson, "On Classification and Treatment of Proximal Humeral Fractures in Ancient Egypt, Greece and Rome”, Ed. Nil Sarı, Ali Haydar Bayat, Yeşim Ülman ve Mary Işın, 38. Uluslararası Tip Tarihi Kongresi Bildiri Kitabı I, (Ankara: TTK Yayınları, 2005), 126. 
normal doğal yapısına dönüşmesine yardımcı olabileceğini belirterek, kas iskelet sisteminde ortopedik cihazlamanın daha çok küçük yaşlarda uygulanmasını özellikle tavsiye etmiştir ${ }^{31}$. Celsus, kırık oluştuğunda en kısa sürede tedaviye yönelik işlemlerin yapılması gerektiğini çünkü kasların kasılıp, sinirlerin gerginleşeceğini bildirmiştir ${ }^{32}$. Atele alma işleminde Antik Çağ'da hekimler, kırıkları tedavi ederken kemiklere birtakım pozisyonlar vererek atele alıp sarmışlardır. Hippokrates, kırıkların pozisyonlanarak atele ve bandaja alınması konusunu, kırılan kemiğin tipine, yerine ve kırık şekline göre farklı yöntemler belirterek uygulamayı ayrıntılı olarak anlatmıştır ${ }^{33}$. Modern tıpta, çocuklarda tüm kırıkların yaklaşık üçte birini oluşturan el bileği kırıklarında ya da ayak bileği kırıklarında redüksiyon işleminden sonra geleneksel alçı kalıpları ve çıkartılabilir atelle cihazlama uygulamaları travmanın vücuttaki yerine göre farklı immobilizasyon şekilleri ile yaygın olarak uygulanmaktadır. Yine çocuklarda alçılama işleminde iyileşmenin hızlı gerçekleştiğini yansıtan kanıtlara rastlanılmıştır ${ }^{34}$. Erken dönemde atel içerisinde kırığın immobilize edilmesi uygulamasının daha iyi sonuçlar elde edebilmede oldukça etkili olduğu görülmektedir.

Hippokrates' in büyük cerrahi tezlerinden biri olan, kırık ve çıkıkların tedavisinde ekstansiyon işleminin doğaya uygun olarak düz bir çizgide yapılması ve kırılan kemiklerin anatomik olarak pozisyonlanması işleminde, örneğin; ön kol kırık ve çıkıklarında çekip uzatma işlemlerini olabildiğince düz bir çizgide yapılmasını ve avuç içi aşağı doğru (pronasyon), avuç içi yukarı doğru (supinasyon) işlemlerini yaparken doğaya uygun bir pozisyonlama uygulanması gerektiğini belirtmiştir. Hippokrates, ok atan, kargı kullanan bir kişinin kırık kemiğinin pozisyonlamasında ok atarken ve karg1 kullanırkenki pozisyona getirilmesinin doğru olmadığını, ok atanların omuzlarını öne uzattıklarında yaptıkları pozisyonda atellemenin yanlış olacağını söylemiştir ${ }^{35}$. Bu işlem uygulanırsa, hastaya hasarın vereceği ağrıdan çok daha fazla ağrı verileceğini açıklamış, Antik Çağ hekimlerinin tekniklerini eleştirmiş ve delillerle bu düşünceyi çürütmeye çalışmıştır.

31 Gal. 138.

32 Cels. De Medicina. VIII. 10.

33 Hippokr. De Fracturis, III. 174.

34 Alwyn Abraham, Helen Handoll ve Tahir Khan, "Interventions for treating wrist fractures in children", Cochrane Database Syst Rev, 3, (2013); Denise E Yeung, Xueli Jia, Clara A Miller ve Simon L Barker, "Interventions for treating ankle fractures in children", Cochrane Database Syst Rev, 1/4, (2016).

35 Hippokr. De Fracturis, I-III. 
Modern çağda, cerrahi ameliyat gerekmeyen durumlarda anatomik pozisyonlamaya çok dikkat edilmektedir ${ }^{36}$. Antik Çağ yaklaşımından farklı olarak ise klinik ve radyolojik faktörlere göre farklı tedavi protokolleri uygulanmaktadır ${ }^{37}$. Hippokrates'in bu tezinin halen geçerliliğini koruduğu anlaşılıyor. Nitekim modern tıpta alçı ile tedavide tıpkı Antik Çağ' da olduğu gibi anatomik kırığın düzgünlügünün sağlanması ve pozisyonlamaya çok dikkat edilmektedir.

Aynı zamanda cerrahi dışı tedavilerde alçı ile immobililizasyon her iki kemiğin deplase olmayan kırıklarında tercih edilmektedir. Örneğin el kırıklarının tedavisinde iyi bir radyolojik tetkikin ardından özel pozisyonlama grafileri yapılmaktadır ve kesin cerrahi endikasyonlar dışında çoğunlukla konservatif olarak tedavi yapılmaktadır. Özellikle yaşlı hastalarda cerrahi riskler ve sinırlı tedavi beklentileri sebebi ile önkol kırıklarında cerrahi dışı yöntemlerden kapalı yerleştirme ve alçılama ile tedavi mümkün olabilmektedir ${ }^{38}$. Bu işlem için günümüzde kalsiyum sülfat hemihidrat moleküllerinin pamuklu beze emdirilmesiyle oluşturulan ve su ile ıslanınca kısa sürede katılaşarak sertleşen alçılı sargılar ve fiberglas ya da poliüretan reçineden üretilen sargılar yaygın olarak kullanılmaktadır ve alçılar hastanın klinik durumuna göre değişik yaklaşımlarla tercih edilmektedir ${ }^{39}$. Tespit uygulaması, iki temel şekilde yapılmaktadır. Birincisi, alçının daha çok geçici olarak tespiti sağlanmak istendiği durum, diğeri ise sirküler alçı ya da atel ile tespit sağlanarak en az komplikasyonla tedavi etme durumudur. Bunun için de uygun materyal kullanımı, doğru teknik uygulama ve doğru endikasyon oldukça önemlidir ${ }^{40}$.

Hippokrates, üst ekstremite kırıklarının tedavisinde bandajlama yöntemini kullanırken, pozisyonlamada hastanın serçe parmağı, dirsek ve

36 Ada ve Bal, "El Kırıklarının Tedavisi", 9-17; Bülent Tanrıverdi ve Mustafa Gökhan Bilgili, "Diz altı Alçı, Diz üstü Alçı, Patellar Tendom Taşıyıcı (PTB) Alçı Uygulamaları", TOTBID (Türk Ortopedi ve Travmatoloji Birliği Derneği) Dergisi, 17, (2018), 307.

37 Gökhun Arıcan, Alper Öztürk ve Kadir Bahadır Alemdaroğlu, "Üst Ekstremite Alçıları ve Endikasyonları: Önkol, Elbilek, El seviyesi Kırıklarına Yönelik Alçılar", TOTBİD (Türk Ortopedi ve Travmatoloji Birliği Derneği)Dergisi, 17, (2018), 271-273.

38 Ayhan Kılıç, Ufuk Özkaya, Yavuz Kabukçuoğlu, Sami Sökücü ve Seçkin Basılgan, "İleri Yaş Döneminde Cerrahi DışıYöntemlerle Tedavi Edilen Radius Alt Uç Kırıklarının Sonuçları", Acta Orthop Traumatol Turc, 43/3, (2009), 232-233.

39 Cem Çopuoğlu ve Murat Erem, "Alt Ekstremite alçıları ve Endikasyonları", TOTBID (Türk Ortopedi ve Travmatoloji Birliği Derneği) Dergisi, S. 17, (2018), 300; Dağlar, "Ortopedi ve Travmatolojide Alçı", 261.

40 Yusuf Alper Katı ve H. Yalçın Yüksel, "Alçı ile Tespitte Temel Prensipler (Çorap, Pamuk Nasıl Sarılır, Kaç Kat Olmalı)”, TOTBID (Türk Ortopedi ve Travmatoloji Birliği Derneği) Dergisi, 17, (2018), 262. 
humerus kemiğinin çıkıntılarını esas almıştır ${ }^{41}$. Ancak kırık ulna (önkol kemiklerinden daha kısa olan) kemiğinde ise Celsus, bandajlamayı uygun görmemiştir ${ }^{42}$. Ön kol kırıklarında bandajlama kolun dirsekten bükük pozisyonu korunarak yapılmıştır ${ }^{43}$. Önkol kırıklarında ayrıca pozisyonlama yapılırken kol yukarda tutularak kanın ekstremiteye doğru akması önlenmiştir ${ }^{44}$.

Celsus, önkolu atele alma işleminde Hippokrates'le aynı yaklaşımı benimsemiş, başparmak göğse doğru çevrilerek pozisyon verilmesini ve sonrasında boyna ask1 yapılarak dirsek seviyesinden biraz yukariya sabitlenmesi gereğini bildirmiştir ${ }^{45}$. Hastanın boynundan asılan bandaj, üst kol kırıklarının tedavisinde ön kolu destekleyecek askı görevi yapmaktadır. Bugün pediatrik grup humerus kırıklarının neredeyse tamamında birincil tedavi yaklaşımı olarak konservatif tedavide ${ }^{46}$ omuz kol askısı sıklıkla tercih edilmektedir. Çocuklarda erişkinlerden biraz daha farklı uygulamalarla konservatif tedavi prosedürü tercih edilmektedir ${ }^{47}$.

Uygulanan tedavi yaklaşımı örneğin, el bileği kırıklarında (distal radius uç kırığı) kol alçısı yapıllyorsa, dirsek pozisyonu 90 derece ve el bileğinin pozisyonu ise 10/15 derece ulnar deviasyon ve 10/20 derece fleksiyonda tutularak alçılama yapılmalıdır. Pozisyonlamalar kısmen benzerlik gösterse de modern tıpta radyolojik görüntüleme tekniklerinin ileri boyutta olmasi kemik kırıklarının tedavisinde şüphesiz ki daha doğru tespitlerin yapılmasını kolaylaştırmaktadır ${ }^{48}$.

Hippokrates, alt ekstremitede hem uyluk hem de bacak kırıklarında topuğun bağlı olduğu ektremite dikkate alınarak yine düz bir şekilde bandaj uygulanmasını önermiştir ${ }^{49}$. Kapalı bacak kırıklarında traksiyonun uyluk ve bacak aynı hizada olacak şekilde traksiyonun kuvvetle çekilerek yapıldıktan sonra bandajlama işlemi ile sabitlenmesi anlatmışıır ${ }^{50}$. Mesela kırık olan

\footnotetext{
${ }^{41}$ Hippokr. De Fracturis, III. 174.

42 Cels. De Medicina. VIII. 10.

43 Hippokr. De Fracturis, XV.

44 Hippokr. De Fracturis, IV. 175.

45 Cels. De Medicina. VIII. 10.

46 Konservatif Tedavi: Tipta takip etme, inaktivite, ilaçla tedavi, fiziksel tedavi, nutrisyonel destek esasına dayanan geleneksel klasik yaklaşımdır. Kırık ve çıkıkların konservatif tedavisi, atel, bandaj, sirküler alçı ve istirahat vd. uygulamaları kapsar.

47 Volkan Kilıçoğlu ve Ahmet Mert, "Shoulder Girdle and Humerus Shaft Fractures", TOTBID (Türk Ortopedi ve Travmatoloji Birliği Derneği) Dergisi, 18, (2019), 346-348.

48 Gökhun Arıcan, Alper Öztürk ve Kadir Bahadır Alemdaroğlu, "Üst Ekstremite Alçıları ve Endikasyonları: Önkol, Elbilek, El seviyesi Kırıklarına Yönelik Alçılar”, TOTBİD (Türk Ortopedi ve Travmatoloji Birliği Derneği)Dergisi, 17, (2018), 271-273.

49 Hippokr. De Fracturis, XXIII.

50 Hippokr. De Fracturis, XV.
} 
ekstremite her iki tarafa eğilirse pronasyon yönünde bir tespit uygulamıştır. Hippokrates bu uygulamanın supinasyon yönündeki tespitten daha az zararlı olduğunu bildirmiştir ${ }^{51}$.

Celsus, özellikle uyluk ve bacak kasları daha dirençli olacağı için vücudun bu kısımlarında oluşan kırıklarda, deri kayış veya keten bantlar eklemlerin her iki ucuna geçirilerek hastanın her iki tarafından zit yönde birkaç kişi tarafından çekme işleminin gerektiğini aktarmıştır. İşlem esnasında ağrının geçmesi ve uzuvların uzunluklarının eşitlenmesi durumunun, işlemin başarılı olduğuna işaret ettiğini bildirmiştir ${ }^{52}$. Tibia kırıklarında (baldır kemiği) ayak ve topuktan uygulanan traksiyondan sonra rotasyonun ayarlanması için ayak aksı ve uyluk açısı değerlendirilerek kırığın lateralde konveks, medialde konkav görünümü düzeltilerek alçılama yapılmaktadır ${ }^{53}$. Günümüzde bacak kırıklarında konservatif tedavi yetişkin hastalarda çok nadir kullanılan bir yöntem olsa da yaşlı, cerrahi tedavi şansı olmayan, ek sistem sorunları olan hastalarda konservatif iskelet traksiyonu bir seçenek olarak tercih edilebilmektedir. Ancak yine de uzun süre yatağa bağlı kalmak hastanın durumunu kötüleştirebilmektedir. Genellikle dört ile sekiz hafta iskelet traksiyonu uygulaması sonrasinda hastaya uygulanan stabil alçı ile egzersiz hareketlerine başlanmaktadır. Kaynama sağlansa bile ekstremitede yanlış açılanma, kısalık, hareket kısıtlılığı yüksek oranda karşılaşılan sorunlar olmaktadır ${ }^{54}$. Modern tıpta çocuklarda alt ekstremite (femur) kırıklarının tedavisinde, tıpkı Antik Çağ'da olduğu gibi çoğunlukla cerrahi olmayan konservatif yöntemlere başvurulmaktadır. Bugün okul öncesi çocuklarda konservatif tedavide oldukça başarılı sonuçlar alınmakta olup, bu konuda en önemli problem, hastanın uzun süre hastanede kalışı ve evde bakım sürelerinin uzun olmasıdır. Çocuk alt ekstremite kırıklarının güncel tedavisinde atelleme, pavlik bandaj, traksiyonu takiben pelvipedal alçılama gibi yöntemlerin yanında gerektiğinde cerrahi olarak ta biyolojik ve konvansiyonel plak tespiti, intramedüller ve eksternal tespitte yapılmaktadir ${ }^{55}$.

51 Hippokr. De Fracturis, I.

52 Cels. De Medicina. VIII. 10.

53 Tanrıverdi ve Gökhan Bilgili, "Diz altı Alçı, Diz üstü Alçı, Patellar Tendom Taşıyıcı (PTB) Alçı Uygulamaları", 308.

54 E. Duman ve Y. Ateş, "Femur Cisim Kırıkları", TOTBID (Türk Ortopedi ve Travmatoloji Birliği Derneği) Dergisi, 7/1-2, (2008), 2.

55 Ünal Salman, Tansel Ünsaldı, Halil Bulanık ve Okay Bulut, "Çocuk Femur Kırıklarının Tedavisinde Erken Pelvi-Pedal Alçılama Yöntemi”, Acta Orthop. Traum.Turc. 22, (1988), 158-160; Bülent Aksoy, Kahraman Öztürk, Ayhan Nedim Kara, Ercan Olcay, Bekir Güven ve Birol Tarık Şener, "Çocuk Femur Kırıklarının pelvi-pedalik Alçı İçinde Cilt Traksiyonu ile Tedavisi ve Erken Sonuçları”, Acta Orthop Traumatol Turc, 30, (1996), 
Hippokrates bandajlama uygulamasında; ilk gün s1k1 bir bandajlamayı şişlik oluşursa ikinci ve devam eden günlerde bandajın gevşetilmesini ancak tekrar sıkılması gerektiğini bildirmiştir ${ }^{56}$. Kırıklarda kullanılan (atel) splintlerin üç günde bir nazik olarak tekrar ayarlanması işlemi yapılmıştır ${ }^{57}$. Bu işlem için Roma Dönemi'nde kullanılan bandajları germe aletleri yapılan arkeolojik kazılarda saptanmıştır ${ }^{58}$.(Şekil 3) Ayrıca Celsus, yaraların bandajla sabitlenme işleminde suturun kullanımından bahsetmiştir ${ }^{59}$.

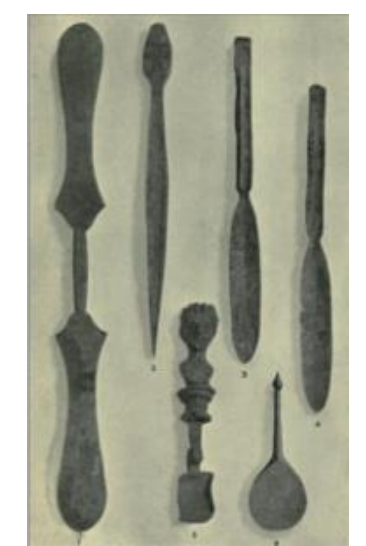

Şekil 3. Kırıklarda bandajları germek için kullanılan aletler. Milne 1907, Surgıcal Instruments in Greek and Roman Times, s. 79.

Hippokrates, bandajlama tekniği olarak her üç günde bir kırığa bir bandajın büyük kuvvet uygulanarak sarılmasını, yedi ve dokuzuncu gün atele alınmasını, eğer iyi pozisyon olmadığı düşünülürse, sargının gevşetip yeniden düzeltilmesini ve tekrar sarılmasını önermiştir. Ayrıca, bandajlama yapılırken kırığın olduğu yere aşırı bask1 yapılmaması, kırık noktasından uzaklaşınca baskının arttırılması gibi ayrıntıları özellikle vurgulamıştır ${ }^{60}$. Bandajların 3. gün yenilenmesini tavsiye etmiştir ${ }^{61}$. Hippokrates, üst kol kemik kırıklarının yaklaşık kırk (40) gün içinde kaynadığını, kırk günün

128-130; Levent Çelebi ve Ali Biçimoğlu, "Çocuk Femur Cisim Kırıkları”, TOTBİD (Türk Ortopedi ve Travmatoloji Birliği Derneği) Dergisi, 5/1-2, (2006), 34-35.

56 Hippokr. De Fracturis, V. 176.

57 Hippokr. De Fracturis, VI. 177.

58 Milne, Surgical Instruments in Greek and Roman Times, New York: Oxford at the Clarendon Press, (1907), 79.

59 Cels. De Medicina. V. 26.

60 Hippokr. De Fracturis, III.

${ }^{61}$ Hippokr. De Fracturis, XXVI. 
sonunda sargıların açılıp bandaj sayısının azaltılmasını önermiştir ${ }^{62}$. Celsus kırıklarda genel bir tedavi yaklaşımı olarak, üç güne kadar kalan bandajların, her gün biraz daha gevşetilmesi gerektiğini bildirmiş, herhangi bir parça dışarı çıkması durumunda ise yerlerine itilerek atellerle sıkıca tutacak şekilde sarılmasını önermiştir ${ }^{63}$. Celsus bandajlama sonrasında ise şaraba ve yağa batırılan keten bezlerle bandajlamanın yapılması gereğini önermiştir ${ }^{64}$.

Hippokrates, kırıkların tedavisinde ateller için kullanılan reçine karışımlardan pek bahsetmese de ${ }^{65}$ kırıklardaki ağrılarda beyaz bal mumlu kompres uygulama gereğini aktarmıştır ${ }^{66}$. Hippokrates bandajların çıkarılma işlemi uygulanırken ise sıcak uygulama yapılıp tekrar bağlamanın gerekli olduğunu belirtmiştir ${ }^{67}$. Nitekim bugün istenilen tedaviye ulaşıldığında en kısa sürede alçıyı çıkartmak ve alçının çıkartılmasında alçı bıçağı gibi malzemeler kullanılmakla birlikte suda gevşetme uygulamaları halen yapılmaktadir.

Hippokrates, kapalı ektremite kırıklarında oluşan şişliklerde ektremite şarap ve yağ ile yıkanarak bandajlamadan önce balmumu ile mesh edilmektedir. Daha sonra ise düzenlenmiş yün ile iyice sarılmaktadır. Doğru ve bol miktarda bandaj uygulayarak şişliklerin daha erken azalması ve kararmasının önlenmesi amaçlanmaktadır ${ }^{68}$. Günümüzde de yine alçının cilde temas etmemesi için alçı malzemesinin altına bir katman olarak pamuk konulmakta ya da hastaya alçı çorabı (sitokinet) giydirilmektedir ${ }^{69}$. Nitekim Yaşlı Plinius, Naturalis Historia'da yüne Romalıların bir dereceye kadar dini önem atfettiklerinden bahsetmiştir. Eserde yünün yumuşatıcı, uyarıcı ve büzücü özelliğine vurgu yapılmış, zaman zaman yağ, şarap veya sirke gibi sıvılarla 1slatılan yünün burkulan uzuvlara, ağrılı sinüslere uygulanması ve bel ağrılarını hafifletmede kullanılmasına değinilmiştir. Özellikle de hayvanın boyun yününün bu uygulamalar için en iyi yün türü olduğu belirtilmiştir. Yine siyriklar, darbeler, ezilme ve çürüklerde, düşmelerde yıkanmamış yünün tercih edilmesi önerilmiş̧tir. Bu bağlamda en iyi yünlerin Galatia, Tarentum, Attika ve Milet'te olduğu bildirilmiştir ${ }^{70}$.

62 Hippokr. De Fracturis, III.

63 Cels. De Medicina. VIII. 10.

${ }^{64}$ Cels. De Medicina. VIII. 10.

65 Hippokr. De Fracturis, III. 174.

66 Hippokr. De Fracturis, XXVII.

67 Hippokr. De Fracturis, VII. 178.

68 Hippokr. De Fracturis, XXI, XXIV.

69 Çopuoğlu ve Erem, "Alt Ekstremite alçıları ve Endikasyonları", 301.

70 Plin. N.H. XXIX, 9. 3-4. 
Hippokrates, kırıkların tedavisinde sıcağın iyileşmeyi sağalayan en önemli etken olduğundan bahsetmiştir ${ }^{71}$. Kapalı yaralı kırıklarda yünü önermesine rağmen, açı yaraya uygulanan şarap ve yağlı yünlü kompres uygulamanın kötü ve yanlış sonuçlar doğuracağını belirtmiştir ${ }^{72}$.

Hippokrates ayrıca, kırıkların tedavisinde bandajlama ve atellemenin yanı sıra, kompres, bal şerbeti, çöpleme otu, kusturucu ilaçlar, kara sakız merhemi ve diyet gibi tedavi programları uygulamıştır ${ }^{73}$. Kusturucu olarak 3 litre suya $1 / 4$ litre çördük otu, içerisine tadını iyileştirmek için sirke ve tuz konularak, önce yavaş geri kalanı hızı bir şekilde içilmesini tavsiye etmiştir. Ayrıca kusturucu olarak acı, tatlı ve asitli üç şarabın karıştırılarak içilmesini önermektedir ${ }^{74}$. Açık kırık tedavisinde Hippokrates, yarayı karasakız merhemi ile yağladıktan sonra üzerine çift kat ince bir kompres uygulamış, etrafinı ise ince bir tabaka yağlı merhem ile yağlamış, geniş bandaj ve geniş sargılar kullanmış, kırık üzerine çok az baskı ile ama çok sayıda bandaj uygulamıştır. Bandajları gün aşırı değiştirmiş, yedi ve dokuzuncu gün ise baskı olmadan atel desteği uygulanmıştır. Ayrıca ölmüş ve siyahlaşmış dokulara temizleme (debritman) işlemi uygulamıştı ${ }^{75}$. Yaradan akan sıvılar içinse yaranın altına keçi derisi serilmesini önermiştir ${ }^{76}$.

\subsection{Kafatası Kırıkları}

Kafa travması tarih boyunca insan sağlığı ile ilgilenenlerin dikkatini çekmiştir. Antik Çağ insanı iskelet sistemi hakkında oldukça geniş bilgilere sahip olduğu için yaralanmalarda kafanın arka kemiğinin ön kısmına göre daha kalın olduğu ve kafanın arkasından alınan darbelerin daha az ölümcül olacağını varsaymışlardır ${ }^{77}$. Kafa travması dışarıdan alınan darbe sonucunda baş bölgesinin yaralanması durumudur. Geç Roma Dönemi'ne (MS 284641) tarihlenen Kütahya Tokul Köyü iskeletlerinin incelenmelerinde, kesin bir tanı olmamakla birlikte bireyin nazaldan (burun) başlayıp sol frontal kemiğe kadar kadar devam eden bir kırık saptanmıştır. Ve ön frontal kemikte oluşan kırığın, kafadan alınan bir travmanın sonucu olabileceği düşünülmüştür ${ }^{78}$. Nitekim bu tür vakalar kişilerarası şiddetin bir sonucu

71 Hippokr. Aforizmalar, V. 22.

72 Hippokr. De Fracturis, XXV.

73 Hippokr. De Fracturis, XXVI.

74 Hippokr. De Fracturis, V.

75 Hippokr. De Fracturis, IX, XXVI.

76 Hippokr. De Fracturis, XXIX.

77 Hippokr. De Articulis, VII. 2.

78 Surul Özlem, A. Cem Erman, Metin Türktüzün, Yarenkür Alkan, Seçil Sağır ve Özcan Şimşek, "Çiledir Höyük Ve Tokul Köyü Şapel Kazısı İskeletlerinin Paleoantropolojik Açıdan Değerlendirilmesi”, XXVII. Arkeometri Sonuçları, (Malatya: T C Kültür ve Turizm 
olabileceği gibi, yaş grubu olarak aile içi çocuğa ya da cinsiyet olarak kadına olan şiddeti yansitan bir veri olarak değerlendirilebilmektedir.

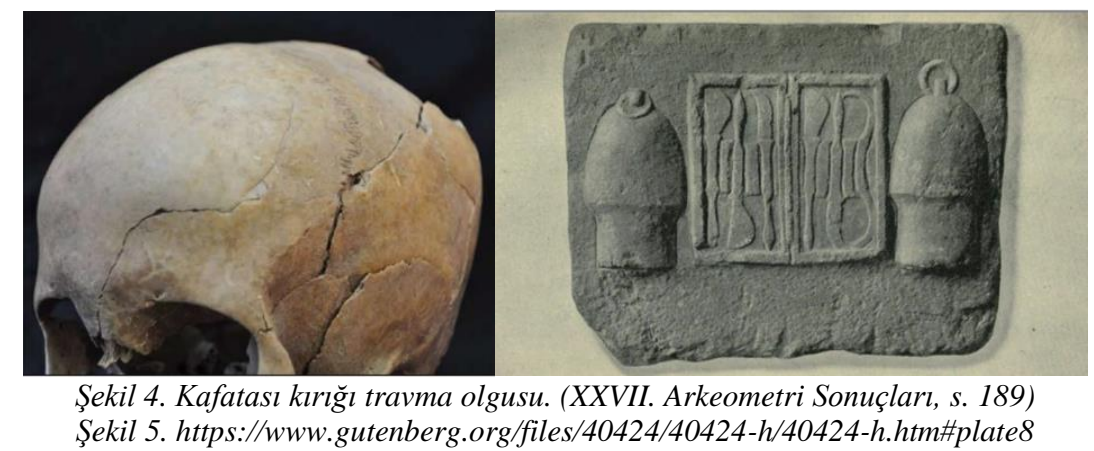

Klasik ve Hellenistik Dönem'e tarihlenen Nif Dağı kazısından elde edilen iki erkek iskeletinin kafatasında travmaya dayalı çöküntü kırıklarına rastlanılmıştır ${ }^{79}$. Geç Roma Dönemi'ne ait Niğde ili Çiftlik ilçesinden elde edilmiş iskeletlerde yapılan paleopatolojik incelemelerde, yaşlı bir erkeğin kafatasında travmaya rastlanırken, erken döneme ait toplulukta kafa travmasına pek rastlanılmadığı tespit edilmiştir ${ }^{80}$. Celsus, Antik Çağ kafaya alınan bir darbe sonucunda kafada kemik kırığının oluşup oluşmadığının anlaşılmasını, hastanın semptomları ile ayırt etmiştir. Hastada eğer bulanık görme, safralı kusma, suskunluk, uyku hali, burundan ve kulaklardan kan gelmesi gibi durumların gözlemlendiğini ifade etmiştir ${ }^{81}$. Nitekim Hippokrates kırılmış, dışarıya çıkıntı yapmış kemiklerin doğru yerlerine oturtulamadığı vakalarda taş duvar ören ustaların kullandığı levyeler tarzında yapılmış bir aletle kemiklerin yerlerine oturtulmasından bahsetmiştir. $\mathrm{Bu}$ işlem eserinde levye, takoz ya da tekerleğin dingili tabirlerini kullanmıştır. Gerek Hippokrates tarafından rezeksiyon işlemi adı altında aktarılan bu anlatım $^{82}$ gerekse Roma Dönemi kemik levyesi ${ }^{83}$ olarak isimlendirilen bir

Bakanlığı Kültür Varlıkları ve Müzeler Genel Müdürlüğü Yayınları, 23-28 Mayıs 2011), 182-183.

79 Ayhan Yiğit, Pınar Gözlük Kırmızıŏlu ve Alper Yener Yavuz, "Nif (Olympos) Dağ Kazısı", XXIII. Arkeometri Sonuçları Toplantısı, (Kocaeli: T C Kültür ve Turizm Bakanlığı Kültür Varlıkları ve Müzeler Genel Müdürlüğü Yayınları, 28 Mayıs-1Haziran 2007), 117.

80 Ali Metin Büyükkarakaya, Yılmaz Selim Erdal ve Metin Özbek, "Tepecik/Çiftlik İnsanlarının Antropolojik Açıdan Değerlendirilmesi”, XXIV. Arkeometri Sonuçları Toplantısı, Ankara: T C Kültür ve Turizm Bakanlığı Kültür Varlıkları ve Müzeler Genel Müdürlüğü Yayınları, 26-30 Mayıs 2008), 126-127.

81 Cels. De Medicina. VIII. 4.

82 Hippokrates, De Fracturis, XXXI-XXXIII. 
aletin (şekil 5) arkeolojik malzemeler arasında saptanmış olması günümüz kırık tedavisinde yaygın olarak tercih edilen cerrahi tedavi yaklaşımını anımsatan bir uygulama olarak karşımıza çıkmaktadır.

Celsus, De Medicina'da ayrıca kemiklerin kesilmesi için kullanılan modiolus adı verilen bir testereden bahsetmiştir. Eserinde hasar gören kemik küçük ise modiolus vasıtasıyla kemiğin kesilmesinden bahsedilirken, kırık büyük ise trepanların kullanıldığını bildirmiştir. Celsus, trepenasyon ${ }^{84}$ işleminin özellikle hasar görmüş kafa kemiğinin çıkarılmasında kullanıldığını yazmıştır. Bu işlem yapılırken (kafatası kemiğinin kesilme işlemi) çok fazla dikkatli olunması gerektiğini bildirmiş, diğer tüm yöntemler denendikten sonra bu işlemin son çare olarak yapılmasını önermiştir. Muhtemel bir yaralanma sonucunda kemik yüzeyinde girintili çıkıntıların olması durumunda ise kazıma ve düzleştirme işlemi yapıldığı bildirilmiştir ${ }^{85}$. Kafatasının parçalı kırığında kemik forsepsi ile kırık kemiklerin temizlendiği aktarılmıştır. Yanlış birleşmiş kemiklerin kırılması işleminde ise kemik testeresi kullanılmıştır ${ }^{86}$.

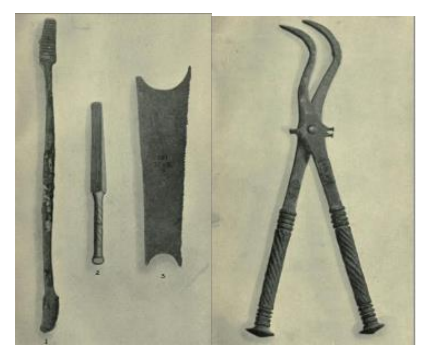

Şekil 6. Kemik kesme işleminde kullanılan testere ve kemik forsepsi. Melni 1907, s. 123, 135.

Celsus, kırık bir kemik tedavi edilmediğinde ciddi iltihaplanmalara neden olabileceğini ifade etmiştir ${ }^{87}$. Kafadan alınan darbelerde, kırıklar oluşabileceği gibi çatlak kemikler de oluşmuş olabilir. Bu durumda cerrahi işlemin tercih edilmiş olması, tedaviyi kolaylaştıracağı gibi kafatası derisinin iyileşmesi de fazla sorun teşkil etmeyeceği düşünülmüştür. Ancak Celsus, hemen her kırık vakasında eski hekimlerin kesme işlemini tercih ettiklerini fakat kafatası için oluşturulmuş olan alçıların tercih edilmesinin daha doğru

83 Ralpy Jackson, Roma Imparatorluğu'nda Doktorlar ve Hastalıklar, Çev.: Şenol Mumcu, (İstanbul: Homer Kitapevi Yayınlar1, 1999), 113-114.

84 Trepanasyon: Beyine ve beyin zarına, kan damarlarına zarar vermeden kafatasından kemikparça çıkartılması işlemidir.

85 Cels. De Medicina. VIII. 3.

86 Melni, Surgical Instruments in Greek and Roman Times, 135.

87 Cels. De Medicina. VIII. 4. 
olacağını ifade etmiştir ${ }^{88}$. Modern tıpta kafa travmasıyla hastaneye gelen hastaların semptomlarının dikkatle değerlendirilmesi ve görüntüleme yöntemleri ile beyin hasar durumlarının tespitinin önemi bilinmektedir. Ayrıca olası hasarın zamanında, eksiksiz ve doğru tespitinin yapılması hayati derecede önemli olduğu, rehabilitasyon gerektiren vakalarda ise disiplinlerarası bir yaklaşımla tedavi prosedürünün belirlenmektedir ${ }^{89}$. Özellikle cerrahi girişimlerin çok riskli olduğu durumlar bilinmekte olup, bu konuda cerrahi tedavi ile konservatif tedaviyi karşılaştıran prospektif ve randomize bulunmamakla birlikte gecikmiş cerrahi gerektiren faktörlerin incelendiği çalışmalar mevcuttur ${ }^{90}$. Nitekim Antik Çağ kafa travmalarında, Hippokrates ve Celsus, öncelikle semptomların değerlendirilmesine dikkat çekmişler, hastada kusma, bilinç kaybı gibi durumların söz konusu olması durumunda ancak cerrahi girişimleri önerdikleri anlaşılmaktadır. Özellikle de dönem şartları düşünüldüğünde cerrahi işlemlerin en son çare olarak tercih edilmiş olması Antik Çağ hekimlerinin kafa travmaları sonucu oluşan kırıkların ne derece önemli sonuçlar doğurabileceğine yönelik öngörülerine işaret etmektedir.

\subsection{Burun Kirıkları}

Travma yüz kısımda gerçekleşmişse burada çoğunlukla burun etkileneceği için burunda gerçekleşen travmada hem burun kemiği hem de kıkırdak kırılma gerçekleşebilmektedir. Bunun yanı sıra burunda tek taraflı kırıklar olabildiği gibi çift taraflı ya da önde ve arkada kırıklar oluşabilmektedir. Celsus, burun kırığının tek taraflı olması halinde kırık olan tarafın daha kalın diğer tarafın daha ince bir rulo ile doldurulmasını tavsiye etmiştir. Çapraz kırıklarda ise her iki burun deliğinin doldurulması gerektiğini bildirmiştir. Tedavinin devamında un ve tütsü isi karışımı sürülmüş deri bir kayış ile kırık burun başa sabitlenmiştir. İki haftanın sonunda 1 l1k su ile yumuşatılan sargı çıartılmış ve burun hareket ettirilebilmiştir. Bu durum açık bir yara ile oluştuğunda bunun tedavisi daha zor olduğu bildirilmiş, böyle durumda bandajlama yapılmaması önerilmiştir ${ }^{91}$. Burun kırıklarında ayrıca kopan kemik kırıkları forsepslerle çıkartılması gibi cerrahi yöntemler uygulanmışsa $\mathrm{da}^{92}$, modern tıpta olduğu

88 Cels. De Medicina. VIII. 4.

89 Koray Kılıç ve Ali Can Yalçın, "Travmatik Beyin Hasarı”, Türk Radyoloji Semineri, 4, (2016), 223-225; Erkut Baha Bulduk ve Serdar Ercan, "Kafa Travmasinda Rehabilitasyon", Türk Nöroşiruji Dergisi, 30/2, (2020), 312-315.

90 Özgiray ve Altınel, "Kafa Travmalarına İlk Yaklaşım”, 590. https://www.researchgate.net/ publication/350557562_Kafa_Travmalarina_Ilk_Yaklasim. 18. 10.2021.

91 Cels. De Medicina. VIII. 5.

92 Milne, Surgical Instruments in Greek and Roman Times, 93. 
gibi büyük bir deforme durumu söz konusu değilse burun kırıklarında da konservatif yöntemlerin tercih edildiği anlaşılmaktadır ${ }^{93}$.

\section{4. Çene Kırıkları}

Hippokrates, çene kırıklarını altın bir tel ile dişleri birbirine sabitleme yöntemiyle tedavi etmiştir ${ }^{94}$. Celsus, çene kırıklarında manipülasyon yöntemini kullanmış, alt çenede iki diş birbirinden farklı yüksekte ise, bunu çene kırığının belirtisi olarak düşünmüş ve at kılı ile dişleri komşu dişe ya da uzaktaki başka dişe bağlanmak suretiyle sabitlemek gereğini bildirmiştir. Üst çene kırığında ise hekim elini iki başparmakları içerde işaret parmaklar dışarda olacak şekilde baskı uygulayarak parçaları pozisyonlamayı anlatmıştır. Sabitleme işlemini diğer kırıklarda olduğu gibi şarap ve yağa batırılmış keten ile bandajlama ve un tütsü karışımı ile bulaştırılıp deri bir kayış ya da bandaj ile başa sabitleme yapılmıştır. Hasta iyileşene dek konuşturulmamasını ve sert gıdalar yememesini önermiştir ${ }^{95}$. Günümüzde çene kırıklarının tedavisi cerrahi olarak plak ve tel osteosentezi uygulamas1, bu tedavinin uygulanamaması durumlarında konservatif yaklaşım ve kombine tedavi yöntemleri yapılmaktadır ${ }^{96}$. Çocuklarda çene bölgesindeki bazı kırıkların tedavisinde de özellikle konservatif tedavi yaklaşımın benimsenmesi noktasında görüşler bulunmaktadır ${ }^{97}$. Geniş bir tedavi yelpazesi çizen çene kırıklarının tedavisinde bugün de hastanın klinik tablosu ve öyküsü oldukça önemlidir. Kırık yüzde asitmetrik görüntü, çiğneme güçlüğü gibi bulgular tanı unsurlarından bazılarını oluşturur. Ayrıca hekim manipülasyon yöntemini teşhis aşamasında kullanarak, açık ve kapalı redüksiyon yöntemleri ile tedaviyi hedeflemektedir. Yine tedavi sürecinde

93 Uğur Yıldırım ve Ender Seçkin, "Evaluating of the Patients with Isolated Nasal Fracture Which Had Been Refered to Erzincan Training And Research Hospital", Arch Basic Clin Res, 2/1, (2020), 11-14.

94 John Stewar Milne, Surgical Instruments in Greek and Roman Times, (New York: Oxford at the Clarendon Press, 1907), 16; http://www.namibiadent.com/the-history-ofdentistry.html

95 Cels. De Medicina.VIII. 7.

96 Orhan Güven, "Tedavi Görmeden İyileşmiş Bir Mandibula Kırığı" Vaka Raporu, G. Ü. Dişhekimliği Fakültesi Dergisi, 2/2, (1985), 219-221; Nevin Büyükakyüz, Merve Öğüt, Natuk Uyumaz ve Murat Öztürk, "Alt Çene Kondil Kırıkları ve Tedavi Yöntemleri”, İstanbul Üniversitesi Diş Hekimliği Fakültesi Dergisi, 44/1, (2010), 58-61.

97 Amit Khatri ve Namita Kalra, "A conservative approach to pediatric mandibular fracture management: outcome and advanteges", Indian Journal of Dental Research, 22/6, (2011), 873-876; Ales Vesnaver, "Dislocated pediatric condyle fractures-should conservative treatment always be the rule?", Journal of Cranio-Maxillofacial Surgery, 48/10, (2020), 933-941; Vrisha Madhuri, Vivek Dutt, Abhay D. Gahukamble ve Prathap Tharyan, "Interventions for treating femoral shaft fractures in children and adolescents", Evid Based Child Health, 9/4, (2014), 753-829. 
sert gıdalardan sakınma gibi önlemlerin benzer şekilde yapıldığı anlaşılmaktadır.

\subsection{Gövde Kırıkları}

Celsus, kaburga kırıklarının iç organlara yakın olması sebebi ile oldukça hassas tedavi gerektirdiğini açıklamıştır. Kırık kaburgaların tamamında değilse şiddetli ağrı, ağızdan kan gelme ve ateş gibi tehlikeler söz konusu olmayabileceğini ancak dokununca hassasiyet oluşması durumunda bandajlama yapılmasını önermiş, diyete özellikle vurgu yapmıştır. Tüm iyileşme boyunca hastanın stresten, öfke, öksürük ve şiddetli bedensel hareketlerden uzak tutulması tavsiye edilmiştir. Komple kırıklarda ise, travma tarafındaki koldan kan alınması önerilmiş, yedi gün süreyle diyetten ekmek çıkartılmıştır. Hastada öksürük varsa, zerdaçal, kimyon ve biber gibi gıdaların hastaya verilmesi ve ağrı varsa arpa unu lapası sürülmesi tavsiye edilmiştir. Lapa, süpürasyonu ${ }^{98}$ (irin birikmesi) önlemesi için kullanılmış ancak yaygın süpürasyon durumunda, dağlama işlemi yapılmıştır. Ayrıca bandajlamanın gevşek tutulması önerilmiştir ${ }^{99}$. Gövde kemiklerinden vücutta en sık kırılan kemik klavikuladır.

Celsus, klavikula kırı̆g 1 tedavisinde hastanın bandajlı olarak yaslanmış bir pozisyonda hareketsiz yaklaşık yirmi günlük bir tedaviyi önermiş, klavicula kırıklarında hareket ettirilmezse bandajsız da iyi olunabileceğini ifade etmiştir. Ancak çıkıntılı kemik kırıklarında uygulanan kurşun gibi ağır maddelerle yapılan basınç uygulama yöntemini, klavikula (köprücük) kemiği kırıklarında tavsiye etmemiştir ${ }^{100}$. Klavikula kırıklarının tedavisinde cerrahi yöntemlerle konservatif yöntemleri bugün fonksiyonel sonuçları bakımından zaman zaman karşılaştırılmış, oluşabilecek birtakım komplikasyonlar yönünden değerlendirilmiş olsa da kırıkların çoğu konservatif olarak tedavi edilebilmektedir ${ }^{101}$.

Antik Çağ omurga kırıkları en az kaburga kırıkları kadar dikkat gerektiren tedavi yaklaşımlarındandır. Bir omurga herhangi bir şekilde kırılmışsa o noktada bir çöküntü mevcuttur ve iğneleme ağrıları söz konusudur. Celsus, hastanın böyle bir durumda öne doğru eğilme reaksiyonu gösterdiğini bildirmiştir ${ }^{102}$. Modern çağda omurga kırıklarında konservatif tedavi gereken durumlarda Antik Çağ'da olduğu gibi uzun yatak istirahatleri

98 Süpürasyon: cerahatlenme, irin oluşup dışarıya akması.

99 Cels. De Medicina. VIII. 9.

${ }^{100}$ Hippokr. De Fracturis, XIV. 1; Cels. De Medicina. VIII. 8.

${ }^{101}$ Alican Barış, Emrah Kovalak, Ozan Beytemur, Gökhan Barbaros, Abdullah Obut ve Ayhan Ethem Unkar, "Erişkin Klavikula Cisim Kırıklarının Konservatif Tedavisi ve Fonksiyonel Sonuçlar”, İstanbul Med, 14, (2013), 40-43. 
ve korselemenin yanında alçı teknikleri ve medikal tedavi yöntemleri halen uygulanmaktadır ${ }^{103}$. Yine pelvis kırıklarının tedavisinde cerrahi ya da konservatif olarak her iki tedavi yaklaşımı arasında uzun vadeli sonuçlar ve komplikasyonlar bakımından çok ta büyük oranlar olduğuna dair kanıtlara rastlanamamıştır ${ }^{104}$.

\subsection{Diyet ve Egzersiz}

Kırık iyileşmesine yaklaşımda, kemiklerde kaynamama ve gecikmiş kaynamaya neden olan faktöreler arasında şüphesiz ki birçok faktör bulunmasının yanı sıra hastanın genel sağlık durumu, aktivite düzeyi ve beslenme durumu oldukça önemlidir. Son yıllarda yapılan çalışmalarda sigara kullanımı kemik kaynamaları ile ilişkilendirilmiştir. Nikotinin kaynama oranına ve kallusun gücüne etkisi kanıtlanmıştır ${ }^{105}$. Celsus, birçok kırık vakasının tedavisi sonrasında çoğunlukla istirahat edilmesini önermiştir ${ }^{106}$.

Hippokrates iyileşme sürecinde hasta hareketsiz kalacağından barsaklarını dinlendirmek için kişinin et ve şaraptan tamamen uzak durması ve dengeli bir diyet ile beslenmesi gerektiğini savunmuştur ${ }^{107}$. Celsus, kaburga kırıklarının tedavisinde yirmi birinci günün ardından sağlam bir beslenme ile kemikleri koruyacak şekilde şişmanlatıcı bir diyet tavsiye etmiştir. Ve günümüzde faydaları kuşkusuz önem kazanan et suyu ile beslenme önerilmiştir. Yaklaşık kırk güne değin süren tedavide onuncu günden sonra ise diyetin normale getirilmesi önerilmiştir ${ }^{108}$. Celsus ise genel olarak kırıklarda oruç diyetinin önemine vurgu yapmıştır. Üçüncü günden itibaren sulu bir diyet ve iltihap giderildiğinde ise daha besleyici bir diyet ile kemiklerin güçlenmesine önem vermiştir. Şarap, kırık tedavi süresince tavsiye edilmemiştir ${ }^{109}$.

102 Cels. De Medicina. VIII. 9.

${ }^{103}$ Haluk Berk, "Sırt-Bel Omur Kırıkları" TOTBID (Türk Ortopedi ve Travmatoloji Birliği Derneği) Dergisi,7/1-2, (2008): 27-28; Şeyho Cem Yücetaş, Kadir Oktay, Tayfun Çakır ve Tahsin Erman, "Torakal (T3-T10) Vertebra Kırıklarına Yaklaşım”, Türk Nöroşirurji Dergisi, 30/3, (2020), 424.

${ }^{104}$ Calderazzi Filippo, Nosenzo Alessandro, Galavotti Cristina, Menozzi Margherita, Pogliacomi Francesco ve Ceccarelli Francesco, "Apophyseal avulsion fractures of the pelvis. A review, Acta Biomedica, 89/4, (2018), 470-476.

105 Nezih Ziroğlu ve Gazi Huri, "Femur Şaft Kaynamama", TOTBID (Türk Ortopedi ve Travmatoloji Birliği Derneği) Dergisi, 16, (2017), 569.

${ }^{106}$ Cels. De Medicina. VIII. 8.

${ }^{107}$ Hippokr. De Fracturis, VII. 178.

${ }^{108}$ Cels. De Medicina. VIII. 9.

${ }^{109}$ Cels. De Medicina. VIII.7. 
Hippokrates, kırık ve çıkıklarda kemik yerine oturtulduktan sonra hastanın ateşi varsa en az on dört gün, yoksa yedi gün boyunca ilk gün hafif dozda çöpleme otu ve katı gıdalardan uzak tutulmasını tavsiye etmiştir. Ayrıca soğuk hiçbir uygulama yapılmamasını önermiştir. Daha sonra ise derecelendirmeli olarak normal diyete geçilebileceğini bildirmiştir ${ }^{110}$. Günümüzde çene ekleminde meydana gelen eklem bozukluklarında da başlangıçta yumuşak diyet uygulaması, fındık, fistık gibi sert kuru yemişlerden kaçınma tedavisi, ufak lokmalar halinde yemek gibi tedavi yaklaşımları benimsenmektedir ${ }^{111}$.

Günümüzde, yüksek kırık riski olan özellikle yaşlı erişkinlerde, kas gücü ve fonksiyonel performansı artırmak için rehabilitasyon ve egzersizin olumlu yönde etkisi kanıtlanmıştır ${ }^{12}$. Aynı şekilde Hippokrates'in de kırık sonras1 tedavide egzersizin önemini vurgulamas ${ }^{113}$ antik hekimlerin bu yöndeki öngörülerine de kanıt oluşturmaktadır.

\section{3. ÇIKIKLAR}

Akut eklem çıkı̆̆ı, eklemin maruz kaldığı kuvvet sonrası eklemleşen yüzeylerin birbirinden tamamen ayrilması durumu olarak tanımlanır ${ }^{114}$. Çıkıklar sıklıkla dirsek, omuz, parmak ve kalçada görülür ve nadir de olsa yaşamı veya ekstremiteyi tehdit edecek ya da kalıcı hasarlara sebep olacak ciddi komplikasyonlara sebep olabilmektedir. Celsus, tıpk1 kırıkların teşhisinde olduğu gibi çıkıklarda da fizik muayene ve bulguların önemli olduğuna vurgu yapmıştır. Celsus, uyluk kemiği çıkıklarının en çok içe doğru oluşmakta olduğunu ve uyluk kemiği çıkıklarında, çıkan tarafta bacağın daha uzun ve eğri olduğunu bildirmiştir. Yürürken topuğun yere değmediğini ya da çıkık oluşan bölgede parmakla tespit edilen bir boşluk olduğunu belirtmiştir ve o bölgede bir çöküklüğün bulunduğunu ifade etmiştir ${ }^{15}$.

\footnotetext{
${ }^{110}$ Hippokr. De Fracturis, XXVI.

${ }^{111}$ Mahmut Yener ve Giray Aynali, "Temporomandibular eklem bozukluklarında tedavi seçenekleri”, Süleyman Demirel Üniversitesi Sağlı Bilimleri Enstitüsü Dergisi, 3/3, (2012), 150-154.

112 Ding-Cheng Chan, Chirn-Bin Chang, Der-Sheng Han, Cian-Hui Hong, Jawl-Shan Hwang, Keh-Sung Tsai ve Rong-Sen Yang, "Effects of exercise improves muscle strength and fat mass in patients with high fracture risk: a randomized control trial", Journal of the Formosan Medical Association, 117/7, (2017), 572-582.

${ }^{113}$ Hippokr. De Fracturis, XXVI.

${ }^{114}$ Nurzat Elmalı, Vahdet Uçan ve Mehmet Kapıcıŏlu, "Akut Çıkıklara Genel Yaklaşım”, TOTBID (Türk Ortopedi ve Travmatoloji Birliği Derneği) Dergisi, 18, (2019), 1-3.

${ }^{115}$ Cels. De Medicina. VIII. 11-25.
} 
Celsus, Antik Çağ çıkık vakalarına erkek çocuklarda ve gençlerde daha sık rastlanıldığını bildirmiştir. Eklemlerin ileri, geri, içe, dışa, bazılarının her yöne bazılarının ise yalnızca belirli bir yöne doğru kaydığını belirtmiștir. Celsus tıpkı kırıkların iyileşmesinde olduğu gibi çıkıkların tedavisinde de hasta kişinin bünyesinin çok önemli olduğunu vurgulamıştır. Hastanın diyetine önem verilmesi gereği, bol bol su içilmesi, ovma işlemi ile masaj yapılıp normal eklem hareketlerine kısa zamanda döndürülmesini önermiştir. Çıkıklar yerleştirilirken zorlanmaları durumunda sinirlerde bir hasar meydana gelebileceğini belirten Celsus, zamanla uzvun zayıflayacağını ve tekrar yerinden çıkabileceğini belirtmiştir. ${ }^{116}$.

Hippokrates, tıpkı kırık tedavisinde olduğu gibi ekstremiteyi sabitleyip, kuvvetle çekip oturtma ve bandajlama tedavisi uygulamıştır ${ }^{17}$. Ayrıca kırık bir uzvu sabitlemek için kullanılan bandajın bir iplik yardımıyla dikilerek işlemin tamamlandığı aktarılmıştır ${ }^{118}$. İster ayak parmakları ister ayak bileği ekleminde oluşan kaymalarda, el kemiklerinde olduğu gibi kemiklerin her birine baskı uygulanarak kemiğin yerine oturtulmasını önermiştir ${ }^{119}$.

Galenos, eklemlerin çıkık tedavisinde Hippokrates'in yöntemini benimsemiş, "aksi yöne gelmeden yerine oturtmak imkansızdır" tezini savunmuştur. Oluşturduğu aparatlarla ekstansiyon/traksiyon işlemlerini uygulamıştır. Bunun için ise bir nevi manüpülasyon yönteminin (ellerin kullanımı) gerekliliğini belirtmiştir ${ }^{120}$.

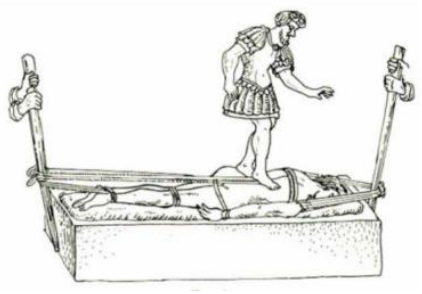

Şekil 7. Galen usulü fitık tedavisi. Jones 2018. Tedavisinde Kullanımı) https://doc.vortala.com/childsites/uploads/284/files/Vax-D-Report.pdf

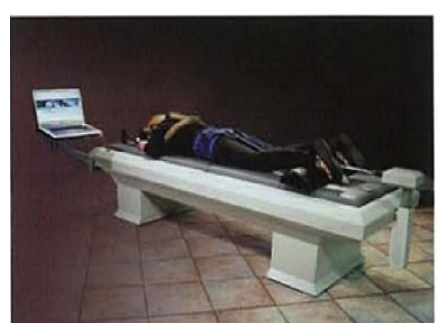
Şekil 8. Vax-D (Kronik Bel Ağrisl
S/uploads/284/files/Vax-D-Report.pdf

Bel ağrısı Antik Çağ’da olduğu gibi günümüzde de en önemli tıbbi ve sosyoekonomik sorunlardan bir tanesidir. Bugün VAX-D (Vertebral

\footnotetext{
${ }^{116}$ Cels. De Medicina. VIII. 11.

${ }^{117}$ Hippokr. De Fracturis, XXXVII.

${ }_{118}$ Milne, Surgical Instruments in Greek and Roman Times, 76.

${ }^{119}$ Hippokr. De Fracturis, IX.

${ }^{120}$ Gal. 83.
} 
Aksiyel Dekompresyon) tedavisi, negatif basınç ile ileri bir teknoloji olarak kronik bel ağrısı şikayetlerinin tedavisinde kullanılmaktadır ${ }^{121}$. Traksiyon tedavisinin en son uygulamalarından biri olan bu yöntem, cerrahi olmayan spinal dekompresyon tedavisidir. Bu uygulamada terapötik bir müdahale olarak, traksiyon yöntemi kullanılmaktadır ${ }^{122}$. Antik Çağ Hippokrates ve Galen'in kullandığı aletleri anımsatan bu ve benzeri tedaviler, bugün var olan prosedürlerin temelini oluşturması açısından önemlidir.

\subsection{Omurga Çıkıkları}

Celsus, omurlarda meydana gelen çıkıklarda omurilik, zar ve sinirler hasar göreceği için tehlikeli olduğunu bildirmiştir. Bir oyuk ya da şişlik söz konusu olduğunu, çıkık diyaframın üst kısmında gerçekleşmişse üst ekstremitede felç oluşacağını, altta gerçekleşirse alt uzuvlarda felç oluşabileceğini ifade etmiştir. Tedavisinde ise dışarıya doğru hafif çıkıklarda hasta yüz üstü yatırılıp gerilerek topukla çıkmış olan omura hafif basılarak yerine oturtulmasını anlatmıştır. Kasların güçlendirilmesi gereğine vurgu yapmıştır, güçlendirilmezlerse çıkığıı tekrarlama riskinin büyük olduğunu söylemiştir. Çıkık fazla olması ya da içe doğru olması durumunda ise herhangi bir işleme gerek olmadığını ifade etmiştir ${ }^{123}$. Modern çağda omurga dislokasyonları genelde cerrahi olarak tedavi edilmektedir. Ancak görüntüleme yöntemleri ve çeşitli medikal aparatların gelişmesi özellikle hafif vakalarda cerrahi dışı yöntemlerini de ön plana çıkarmıştır. Uygulanan konservatif tedaviler arasinda traksiyona alma, ortezler, korseleme, manipülasyon ve mobilizasyon teknikleri kullanılmaktadır ${ }^{124}$.

\subsection{Ekstremite Çıkıkları}

Hippokrates, alt ekstremite çıkıklarında yerine oturtma tedavisinin, üst ekstremitelerden daha dikkatli bir şekilde yapılmasını önermiş̧ir. Ayrıca hastanın istirahatinin çok önemli olduğunu, kemikler yerine tamamıyla

${ }^{121} \mathrm{https}: / /$ doc.vortala.com/childsites/uploads/284/files/Vax-D-Report.pdf

${ }^{122}$ Aynur Demirel, "Lumbal Disk Herniasyonunda Farkl Tedavi Yöntemlerinin Karşılaştırılması" (Yayınlanmamış Doktora Tezi, Hacettepe Üniversitesi, 2015), 24-27; Dwain M. Daniel, "Non-surgical Spinal Decompression Therapy: Does the Scientific Literature Support Efficacy Claims Made in the Advertising Media", Chiropractic\&Osteopathy, 15/1, (2007), 1-5; Kanji, Giresh and Peter Menhinick. "Prospective randomised controlled study of VAX-D and TENS for the treatment of chronic low back pain." Australasian Musculoskeletal Medicine, 21,( 2017), 40.

${ }^{123}$ Cels. De Medicina. VIII. 14.

${ }^{124}$ Burak Bahadır ve Yusuf Şükrü Çağlar, "Servikal Travmalarda Konservatif Tedavi: Traksiyon Teknikleri ve Cerrahi Tedavi için Zamanlama”, Türk Nöroşirurji Dergisi, 30/3, (2020), 364-369. 
oturmadığında ya da hata yapıldığında kalça, uyluk ve bacağın giderek işlevini kaybedeceğini bildirmiştir. Çıkık içeri doğru olduğunda dış kısım, dışarı doğru olduğunda ise iç kısmın hasar göreceğini ifade etmiştir ${ }^{125}$.

Antik Çağ kemik çıkıklarında traksiyon uygulaması, her uzuv için kemikler arasında bir boşluk kalıncaya kadar zıt yönde çekilme ile yapılmıştır. Ancak uzatma yöntemleri kasların kuvvetine ve kemiklerin anatomik yapısına göre çeşitlilik göstermektedir. Bu işlem için bazen iki el bazen de kayışlar kullanılmıştır. Ancak özel bazı hususlar söz konusudur. Uyluk çıkığının tedavisinde uzuv zayıfsa kasıktan bir kayışla gerdirmek yeterlidir. Hasta normal ya da güçlü ise, hasta yatırılır. Kaslar gerildiğinde kemik öne geliyorsa kasık üzerine yuvarlak bir cisim konulur. Hastanın dizi ani bir hareketle geri çekilir. Uyluk bükülebildiği anda kemik yerine yerleşmiştir. Yalnız bu uygulama yapılırken bağlar ve kasların yırtılma tehlikesi söz konusudur. Hasta oldukça uzun süre yatakta yatırılmalı hareket ettirilmemelidir. Uyluk çıkıklarında uygulanan yöntem ile diz çıkıklarında uygulanan tedavi aynıdır. Sadece dizin geriye çıkıklarında diz arkasına yuvarlak bir top konularak diz bükülerek yerine oturtulmalıdır ${ }^{126}$.

Hippokrates ve devaminda Galenos tarafindan kabul edilip uygulanan bir yöntemle, doğuştan kalça çıkı̆̆ tedavi edilebilmekte idi. Tek taraflı ya da iki taraflı gelişebilen bu tür çıkıklarda çocukların uygun şekilde fizik tedavi eğitimi alırlarsa sağlıklı bacaklarının üzerinde dik durabildikleri ya da koltuk altı değneği kullanılırsa sağlıklı taraftan destek bulabildikleri aktarılmıştır. Ayrıca erken teşhis ve tedavinin önemli olduğu bu durumlarda bir bacak kısa olacağı için özel tasarım ayakkabıların kullanımı gibi tedavi yaklaşımları benimsenmiştî ${ }^{127}$.

Celsus, ayak bileği çıkıklarının öne doğru ise manipülasyon gerekebileceğini ve ayak bileği kasları, sinir ve tendomlarının vücut ağırlığını taşıdığı için ayağın istirahate alınması gerektiğini böylelikle tekrar burkulması ve çıkmasının önlenmesini tavsiye etmiştir. Bandaj uygulanıp ilk başta ayak bağcıklarının zarar görmemesi için alçak ayakkabılar tercih edilmesini önermiştir. Ayak parmak çıkıklarının da yine atelle sabitlenmesi gereğini bildirmiştir ${ }^{128}$.

\footnotetext{
${ }^{125}$ Hippokr. De Fracturis, IV-XV.

${ }^{126}$ Cels. De Medicina. VIII. 20-25.

${ }^{127}$ Revelou, MT, A. Eleftheriou, G. Fezoulidi, P. Hatzikyriakou, V. Raoulis, G. Tsoucalas,

"Corpus Hippocraticum'da Konjenital Ortopedik Topal Deformiteler", Uluslararast Ortopedi (SICOT), 43, (2019), 1994-1997.

${ }^{128}$ Cels. De Medicina. VIII. 20-25.
} 


\section{3. Omuz Çıkıkları}

Modern tıpta olduğu gibi Antik Çağ'da omuz çıkıklarına oldukça sık rastlanılmıştır. Günümüzde omuz çıkıkları için çok farklı redüksiyon yöntemleri kullanılmakta olsa da geleneksel olarak en fazla kullanılan yöntemlerden bir tanesi, Hippokrat yöntemi olarak bilinen yöntemdir ${ }^{129}$. Hippokrates, omuz çıkıklarında en bariz belirtinin sağlam kolda olduğu gibi çıkık oluşan kolun kulağa kaldırılamaması olduğunu bildirmiştir ${ }^{130}$.

Celsus eserinde omuz ve kalça çıkıklarında ölüm riskinin söz konusu olduğunu bildirmiştiir ${ }^{131}$. Eserinde omuz çıkıklarının tedavisinde (güçlü kaslara sahip kişilerde) koltuk altından parmaklara kadar uzanan bir tahtadan faydalandığını anlatmıştır. Tahtanın hastanın koltuk altına gelen kısmı yuvarlak olup, humerus başının küçük bir kısmını alacak şekilde hafif oyulmuştur. Tahtanın üç yerinden aralarında birer boşluk olacak şekilde yumuşak kayışların geçirildiği iki yuva bulunmaktadır. Kayışlardan biri humerus başının hemen altından ikincisi dirseğin biraz üstünde, üçüncüsü bileğe bağlıdır. Temasla yaralanmayı önleyecek şekilde bandajla kapatılan tahtanın üst ucu koltuk altına uygulanır. Çıkık uzuv yukarıya doğru itilerek hekim kolu dirsekten aşağıya ve yana doğru iterek omuzu yerine oturtur. Zayıf kaslı kişiler için ise hasta tabureye oturtulur, asistanın birisi çıkık kemiğin başını hafifçe bastırırken diğer asistan ön kolu esnetir. Arkada oturan hekim bir elini hastanın koltuk altına sokarak kemiğe bastırır ve omuzu yerine oturtur. İkinci olarak hasta önce ayakta iken tahta bir merdiven basamağına sabitlenen kol aşağı doğru çekilirken hastada çömelme pozisyonundadır. Omuz böylece yerine oturtulur. Üçüncü yöntem olarak, hasta sırt üstü yatırılır. Koltuk altından deri kayış bandaj geçirilir. Uçları hastanın başının arkasında bir asistana verilir. Ön kolu başka bir asistan hastayı çekerek sabitler. Hekim, sağ eliyle dirseği üst kolla birlikte kaldırır. Omuzu yerine oturtur. Omuz oturtulduktan sonra hastanın koltuk altı yünle doldurulup kemiğin kayması engellenip sabitlenerek bandajlanır ${ }^{132}$. Antik Çağ yöntemlerini anımsatan günümüz uygulamalarında ise, doktor hastanın çıkık olan omuz yönünde bir eli ile hastanın el bileğini tutar. Diğer eliyle dirseği kavrayacak şekilde tutarak, 90 derece fleksiyon ve omuz ekleminden 20 derece öne doğru fleksiyon ve redüksiyonu sağlamak için kola paralel olana kadar diş rotasyona getirerek omuzu yerine oturtma işlemi

${ }^{129}$ Murat Gül, Umut Yavuz, Sami Sökücü, Engin Çetinkaya, Yavuz Arıkan ve Yavuz Selim Kabukçuoğlu, "Omuz Çıkığında Fleksiyon-Addüksiyon-Dış Rotasyon Yöntemi”, Acta Orthop Traumatol Turc, 48/2, (2014), 166.

${ }^{130}$ Hippokr. De Articulis, X.

${ }^{131}$ Cels. De Medicina. VIII. 25.

${ }^{132}$ Cels. De Medicina. VIII. 15-16. 
uygulamaktadır ${ }^{133}$. Benzer yöntemler hastanın kas, sinir, damar ve kemik muayenesi yapılarak radyolojik görüntüleme eşliğinde redüksiyon manevrası olarak tercih edilmektedir. Manevra öncesinde hastaya lokal anestezi ve sedatif ilaçlar verilerek hastanın rahatlaması ve kaslarının gevşemesi sağlanır ${ }^{134}$. Özellikle çarşaf yöntemi ve Kocher manevrası gibi redüksiyon yöntemleri, Antik Çağ uygulamalarını anımsatmaktadır.

\section{SONUÇ}

Antik Çağ'da iskelet kırık ve çıkıklarının tedavisinde çoğunlukla fonksiyonel immobilizasyon mantığı ve cerrahi olmayan teknikler benimsenmiş olup, bugün modern tıpta konservatif tedavinin kökenine işaret eden yaklaşımlar ideal tedavi yöntemi olarak görülmüştür. Modern tıpta, cerrahi teknikler, anesteziyoloji bilimi ve görüntüleme yöntemleri, iskelet kırık ve çıkıklarının tedavisini büyük oranda değiştirmiştir. Ancak cerrahi tedavi sonunda oluşabilecek komplikasyonlar ve maliyet gibi nedenlerle akut yaralanmalarda konservatif tedavi halen geçerliliğini korumaktadır. Yine bazı kırık vakalarında klinik tablo ve uzun vadeli sonuçlar bakımından değerlendirildiğinde özellikle çocuklarda bacak (femur) ve kol (humerus) kırıklarında yaygın olarak uygulanmaktadır. İleri yaştaki hastalarda ya da ameliyatı engelleyen belirgin bir komorbiditesi olan yetişkinlerde de özel durumlar dışında literatürde bu yaklaşım benimsenmektedir. Görülüyor ki Konservatif tedavi uygulamaları Antik Çağ' da olduğu gibi bugün, hastalık nedeniyle bozulan iş ve sosyal yaşam performansının tam olarak düzeltilmesi ve kişilerin günlük yaşam aktivitelerine en kısa zamanda dönmelerinin sağlanması ve hastaya hızlı ve tam iyileşme olanağı sunması bakımından öncelikli olarak tercih edilmektedir.

Hippokrates ve Celsus gibi antik yazarların eserleri incelendiğinde, tedavide uygulanan traksiyon, ekstansiyon, manipülasyon, mobilizasyon ve bandajlama teknikleri ile kırı parçalarının tekrar eski haline getirilmesindeki pozisyonlama işlemine verilen önem ve sabitleme yöntemleri bugünkü modern tıpla benzerlikler göstermektedir. Kasların kuvveti ve kemiklerin anatomik yapısı göz önünde bulundurularak kemikler arasında boşluk oluşuncaya kadar zıt yönde çekme olarak uygulanan traksiyon işlemi bugün bel ağrılarının tedavisinde cerrahi olmayan spinal dekompresyon tedaviyi kısmen de olsa anımsatmaktadır. Modern

${ }^{133}$ Murat Gül, Umut Yavuz, Sami Sökücü, Engin Çetinkaya, Yavuz Arıkan ve Yavuz Selim Kabukçuoğlu, "Omuz Çıkığında Fleksiyon-Addüksiyon-Dış Rotasyon Yöntemi”, Acta Orthop Traumatol Turc, 48/2, (2014), 165.

${ }^{134}$ Nurzat Elmalı, Vahdet Uçan ve Mehmet Kapıcıoğlu, "Akut Çıkıklara Genel Yaklaşım”, TOTBID (Türk Ortopedi ve Travmatoloji Birliği Derneği) Dergisi, 18, (2019), 1-3. 
teknolojinin gelişmesi ile değişik traksiyon aparatları yaygın olarak kırık tedavisinde uygulanmaktadır.

Hippokrates'in büyük cerrahi tezi olan bandajlama ve atele alma işleminde pozisyonlamanın, organın anatomik düzgünlügünün sağlanmasındaki rolü ön plana çıkarılmıştır. Bu amaçla (MÖ 2750-2625) Erken Mısır tıbbından beri bilinmekte olan alçı uygulaması, Yunan ve Romalı hekimler tarafından atelleme işleminde kullanılmış olup bugün alçı teknikleri ve medikal tedavi yöntemleri kırık tedavisinde halen tercih edilmektedir. Yaşlı Plinius eserinde kırık ve çıkık vakalarında kullanılan yüne Romalılar'ın atfettikleri dini önemi vurgularken, günümüzde alçılama işlemi esnasında kullanılan alçı çorabı, alçı pamuğu gibi materyallerin tedavi protokolünde önemini halen koruduğu bilinmektedir.

Antik Çağ' da hastanın genel muayenesi, hastadan iyi bir öykü alma ve klinik bulgular açısından değerlendirilmesi, bugün de oldukça önem verilen bir husustur. Ayrıca kırık ve çıkıkların tedavisinde semptomlara yönelik ve hastaya özgü tedavilerin benimsenmiş olması ve diyete verilen rol bugün önemini halen devam ettirmektedir.

İskelet sistemi travmaları son y1llarda ayrı bir bilim dalı olarak Ortopedi ve Travmatoloji uzmanları tarafından modern teknolojilerle tedavi edilmektedir. Modern tıbbın gelişmiş yöntemlerine rağmen, bugün kırık çıkıklı hastaların halen kırık çıkıkçı adı altında kişilerden medet umarak bilinçsizce ve çoğunlukla da sakatlıkla sonuçlanan uygulamalara maruz kalmalarının o derece yanlış ve ilkel bir yaklaşım olduğunu belirtmekte de fayda görülmektedir. 


\section{KAYNAKÇA}

\section{Antik Kaynaklar}

Cels.

AULUS CORNELIUS CELSUS. De Medicina.

De Medicina, Çev.: W. G. Spencer, Cambridge, 1971.

Gal.

GALENOS. Tip Sanatının Anayasası Tip Sanatı Glaukon'a Tedavi

Hippokr. HIPPOKRATES. De Articulis. De Articulis, Ed. Charles Darwin Adams, New York, 1868.

HIPPOKRATES. De Fracturis.

De Fracturis, Ed. Charles Darwin Adams, New York, 1868.

HIPPOKRATES. Aforizmalar.

Aforizmalar, Eyüp Çoraklı (Çev.), Türkiye İș Bankası Kültür Yayınları, İstanbul, 2020.

Plin.

YAŞLI PLINIUUS/ GAINNUS PLINIUS SECUNDUS.

The Naturalis Historia, Ed. John Bostock, London, 1855.

\section{Modern Kaynaklar}

Abraham, Alwyn, Helen Handoll ve Tahir Khan. "Interventions for treating wrist fractures in children", Cochrane Database Syst Rev, 3, 2013.

Ada, Sait ve Emin Bal. "El Kırılarının Tedavisi", TOTBID (Türk Ortopedi ve Travmatoloji Birliği Derneği) Dergisi, 3/1-2, (2004): 9-18.

Aksoy, Bülent, Kahraman Öztürk, Ayhan Nedim Kara, Ercan Olcay, Bekir Güven ve Birol Tarık Şener. "Çocuk Femur Kırıklarının pelvi-pedalik Alçı İçinde Cilt Traksiyonu ile Tedavisi ve Erken Sonuçları", Acta Orthop Traumatol Turc, 30, (1996): 128-130.

Arıcan, Gökhun, Alper Öztürk ve Kadir Bahadır Alemdaroğlu. "Üst Ekstremite Alçıları ve Endikasyonları: Önkol, Elbilek, El seviyesi Kırıklarına Yönelik Alçılar", TOTBID (Türk Ortopedi ve Travmatoloji Birliği Derneği) Dergisi, 17, (2018): 268-280.

Aşkit, Çağatay. "Soranus'Tex “On Signs of Fractures”", Archivum Anatolicum 12/2, (2018): 13-30.

Bahadır, Burak ve Yusuf Şükrü Çağlar. "Servikal Travmalarda Konservatif Tedavi: Traksiyon Teknikleri ve Cerrahi Tedavi için Zamanlama", Türk Nöroşirurji Dergisi, 30/3, (2020): 364-369.

Barış, Alican, Emrah Kovalak, Ozan Beytemur, Gökhan Barbaros, Abdullah Obut ve Ayhan Ethem Unkar. "Erişkin Klavikula Cisim Kırıklarının Konservatif Tedavisi ve Fonksiyonel Sonuçlar", İstanbul Med, 14, (2013): 40-43.

Bayat, Ali Haydar. Tlp Tarihi, İstanbul: Merkezefendi Geleneksel Tip Derneği Yayınları, 2010. 
Berk, Haluk. "Sirt-Bel Omur Kırıkları" TOTBIDD (Türk Ortopedi ve Travmatoloji Birliği Derneği) Dergisi,7/1-2, (2008): 27-28.

Breasted, James Henry. The Edwin Smith Surgical Papyrus, Vol I, Chicago: The University of Chicago Press, 1930.

Brorson, Stig. "On Classification and Treatment of Proximal Humeral Fractures in Ancient Egypt, Greece and Rome", ed. Nil Sarı, Ali Haydar Bayat, Yeşim Ülman ve Mary Işın. 38. Uluslararası Tip Tarihi Kongresi Bildiri Kitabı I. 125-128. Ankara, 2005.

Brorson, Stig. "Management of Fractures of the Humerus in Ancient Egypt, Greece, and Rome: AnHistorical Review", Clinical Orthopaedics and Related Research, 467/7, (2009): 1907-1914.

Bujalkova, Maria. "Rufus of Ephesus and his contribution to the devalopment of anotomical nomenclature", AMHA-Acta Medico Historica Adriatica, 9/1, (2011): 89-100.

Buldukt, Erkut Baha ve Serdar Ercan. "Kafa Travmasinda Rehabilitasyon", Türk Nöroşiruji Dergisi, 30/2, (2020): 312-316.

Büyükakyüz, Nevin, Merve Öğüt, Natuk Uyumaz ve Murat Öztürk. "Alt Çene Kondil Kırıkları ve Tedavi Yöntemleri”, İstanbul Üniversitesi Diş Hekimliği Fakültesi Dergisi, 44/ 1, (2010): 55-61.

Büyükkarakaya, Ali Metin, Yılmaz Selim Erdal ve Metin Özbek. "Tepecik/Çiftlik İnsanlarının Antropolojik Açıdan Değerlendirilmesi”, XXIV. Arkeometri Sonuçları Toplantısı. 119-138. Ankara: T C Kültür ve Turizm Bakanlığı Kültür Varlıkları ve Müzeler Genel Müdürlüğü Yayınları, 2008.

Chan, Ding-Cheng, Chang, Chirn-Bin, Han, Der-Sheng, Hong, Cian-Hui, Hwang, Jawl-Shan, Tsai, Keh-Sung ve Yang, Rong-Sen. "Effects of exercise improves muscle strength and fat mass in patients with high fracture risk: a randomized control trial", Journal of the Formosan Medical Association, 117/7, (2017): 572-582.

Çelebi, Levent ve Ali Biçimoğlu. "Çocuk Femur Cisim Kırıkları". TOTBID (Türk Ortopedi ve Travmatoloji Birliği Derneği) Dergisi, 5/1-2, (2006): 34-43.

Çopuroğlu, Cem ve Murat Erem. "Alt Ekstremite alçıları ve Endikasyonları", TOTBID (Türk Ortopedi ve Travmatoloji Birlĭgi Derneği) Dergisi, 17, (2018): 300-305.

Dağlar, Bülent. "Ortopedi ve Travmatolojide Alçı", TOTBID (Türk Ortopedi ve Travmatoloji Birliği Derneği) Dergisi, 17, (2018): 259-261.

Daniel, Dwain M. "Non-surgical Spinal Decompression Therapy: Does the Scientific Literature Support Efficacy Claims Made in the Advertising Media", Chiropractic\&Osteopathy, 15/1, (2007): 1-5.

Demirel, Aynur. "Lumbal Disk Herniasyonunda Farklı Tedavi Yöntemlerinin Karşılaştırılması”, Yayınlanmamış Doktora Tez, Hacettepe Üniversitesi, 2015. 
Demirtaş, A. Mehmet ve Mahmut Kalem, "Erişkinlerde Önkol Kırıkları”, TOTBIDD (Türk Ortopedi ve Travmatoloji Birliği Derneği) Dergisi, 7/1-2, (2008): 35-39.

Duman, E ve Y. Ateş. "Femur Cisim Kırıkları", TOTBID (Türk Ortopedi ve Travmatoloji Birliği Derneği) Dergisi,7/ 1-2, (2008): 1-7.

Elmalı, Nurzat, Vahdet Uçan ve Mehmet Kapıcıŏlu. “Akut Çıkıklara Genel Yaklaşım”, TOTBID (Türk Ortopedi ve Travmatoloji Birliği Derneği) Dergisi, 18, (2019): 1-10.

Filippo, Calderazzi, Nosenzo Alessandro, Galavotti Cristina, Menozzi Margherita, Pogliacomi Francesco ve Ceccarelli Francesco. "Apophyseal avulsion fractures of the pelvis. A review, Acta Biomedica, 89/4, (2018): 470-476.

Gül, Murat, Umut Yavuz, Sami Sökücü, Engin Çetinkaya, Yavuz Arıkan ve Yavuz Selim Kabukçuoğlu. "Omuz Çıkığında Fleksiyon-Addüksiyon-Dış Rotasyon Yöntemi”, Acta Orthop Traumatol Turc, 48/2, (2014): 164-168.

Güven, Orhan. "Tedavi Görmeden İyileşmiş Bir Mandibula Kırığı” Vaka Raporu, G. Ü. Dişhekimliği Fakültesi Dergisi, 2/ 2, (1985), 217-221.

Hernigou, Philippe. "Plaster of Paris: the orthopaedic surgeon heritage", Orthopaedic Heritage, 40, (2016): 1767-1778.

Jackson, Ralpy. Roma Imparatorluğu'nda Doktorlar ve Hastalıklar, Şenol Mumcu (Çev.), İstanbul: Homer Kitapevi Yayınları, 1999.

Jones, Indiana. Antikçağ'da Tip Aletleri ve Tedavi Yöntemleri, 2018.

Joshi, Nikita, Alena Lira, Ninfa Mehta, Lorenzo Paledino ve Richard Sinert. "Diognostic Accuracy, Physical Examination, and Bedside Ultrasound for Diagnosis of Extremity Fractures in the Emergency Department: A Systematic Review", Academic Emergency Medicine, 20/1, (2013): 1-15.

Kanji, Giresh ve Peter Menhinick. "Prospective randomised controlled study of VAX-D and TENS for the treatment of chronic low back pain." Australasian Musculoskeletal Medicine, 21, (2017): 40.

Katı, Yusuf Alper ve H. Yalçın Yüksel. “Alçı ile Tespitte Temel Prensipler (Çorap, Pamuk Nasıl Sarılır, Kaç Kat Olmal1)", TOTBID (Türk Ortopedi ve Travmatoloji Birliği Derneği) Dergisi, 17, (2018): 262-267.

Khatri, Amit ve Namita Kalra. "A conservative approach to pediatric mandibular fracture management: outcome and advanteges", Indian Journal of Dental Research, 22/6, (2011): 873-876.

Kılıç, Ayhan, Ufuk Özkaya, Yavuz Kabukçuoğlu, Sami Sökücü ve Seçkin Basılgan. "İleri Yaş Döneminde Cerrahi Dışı Yöntemlerle Tedavi Edilen Radius Alt Uç Kırıklarının Sonuçları”, Acta Orthop Traumatol Turc, 43/3, (2009): 229-234.

Kılıç, Koray ve Ali Can Yalçın. "Travmatik Beyin Hasarı”, Türk Radyoloji Semineri, 4, (2016): 211-228.

Kılıçoğlu, Volkan ve Ahmet Mert. "Shoulder Girdle and Humerus Shaft Fractures", TOTBID (Türk Ortopedi ve Travmatoloji Birliği Dernĕgi) Dergisi, 18, (2019): 346-348. 
Leake, Chauncey D. The Old Egyptian Medical Papyri, Laweance: University of Kansas Press, 1952.

Madhuri, Vrisha, Vivek Dutt, Abhay D. Gahukamble ve Prathap Tharyan. "Interventions for treating femoral shaft fractures in children and adolescents", Evid Based Child Health, 9/4, (2014): 753-829.

Mashouf, Mehryar. "The Edwin Smith Surgical Papyrus”, ed. Nil Sarı, Ali Haydar Bayat, Yeşim Ülman ve Mary Işın, 38. Uluslararası Tip Tarihi Kongresi Bildiri Kitabl I. 25-32. Ankara, 2005.

Milne, John Stewar. Surgıcal Instruments in Greek and Roman Times, New York: Oxford at the Clarendon Press, 1907.

Newton-Tringgs Lynne, H. Pugh, J. Rogers ve A. Timms. "Key Musculoskeletal Interventions", ed. S. Clarke ve J. Tomlinson, Orthopaedic and Trauma Nursing, (2014): 80-95.

Ortner, Donald, J. ve Walter G. J. Putschar. Identification of Pathological Conditions Human Skeletal Remains, Wahington: Smithsonian Institution Press, 1981.

Özbek, Metin. "Anadolu Eski İnsan Topluluklarında Sağlık Sorunları", Hacettepe Üniversitesi Edebiyat Fakültesi Dergisi, 10/2, (1993): 1-19.

Öztürk, Alper ve Önder Ersan. "Lower Extremity Skeletal Tractions", TOTBID (Türk Ortopedi ve Travmatoloji Derneği) Dergisi, 17, (2018): 327-331.

Revelou, MT., A. Eleftheriou, G. Fezoulidi, P. Hatzikyriakou, V. Raoulis ve G. Tsoucalas. "Corpus Hippocraticum'da Konjenital Ortopedik Topal Deformiteler”, Uluslararası Ortopedi (SICOT), 43, (2019): 1993-1998.

Sağır, Mehmet, Özer İsmail, Satar Zehra, Güleç Erksin Savaş. "Stratonikeia İskeletlerinin Paleoantropolojik Analizi", XXVIII. Arkeometri Sonuçları Toplantısı. 59-68. Çorum: T C Kültür ve Turizm Bakanlığı Kültür Varlıkları ve Müzeler Genel Müdürlüğü Yayınları, 2012.

Salman, Ünal, Tansel Ünsaldı, Halil Bulanık, Okay Bulut. "Çocuk Femur Kırıklarının Tedavisinde Erken Pelvi-Pedal Alçılama Yöntemi”, Acta Orthop. Traum.Turc. 22, (1988):158-160.

Smith, G. Elliot. "The Most Ancient Splints", British Medical Journal I, (1908): 732-737.

Standring, Susan. "Abrief history of topographical anatomy", Journal of Anatomy, 229, (2016): 32-62.

Surul Özlem, A. Cem Erman, Metin Türktüzün, Yarenkür Alkan, Seçil Sağır, Özcan Şimşek. "Çiledir Höyük Ve Tokul Köyü Şapel Kazısı İskeletlerinin Paleoantropolojik Açıdan Değerlendirilmesi”, XXVII. Arkeometri Sonuçları. 179-190. Malatya: T C Kültür ve Turizm Bakanlığı Kültür Varlıkları ve Müzeler Genel Müdürlüğü Yayınları, 2011. 
Tanrıverdi, Bülent ve Gökhan Bilgili Mustafa. "Diz altı Alçı, Diz üstü Alçı, Patellar Tendom Taşıyıcı (PTB) Alçı Uygulamaları", TOTBID (Türk Ortopedi ve Travmatoloji Birliği Derneği) Dergisi, 17, (2018): 306-314.

Uzel, İlter. Anadolu Tip Tarihi’ne Giriş, İstanbul: Türk Eskiçağ Bilimleri Enstitüsü Yayınları, 2008.

Vesnaver, Ales. "Dislocated pediatric condyle fractures-should conservative treatment always be the rule?", Journal of Cranio-Maxillofacial Surgery, 48/10, (2020): 933-941.

Yavuz, İbrahim Alper, Cahit Koçak ve Fuad Öken Özdamar. “İskelet Traksiyonunda Temel Prensipler", TOTBID (Türk Ortopedi ve Travmatoloji Birliği Derneği) Dergisi, 17, (2018): 315-323.

Yener, Mahmut ve Aynali Giray. "Temporomandibular eklem bozukluklarında tedavi seçenekleri”, Süleyman Demirel Üniversitesi Sağlık Bilimleri Enstitüsü Dergisi, 3/3, (2012): 150-154.

Yeung, Denise E, Xueli Jia, Clara A. Miller, ve Simon L. Barker. "Interventions for treating ankle fractures in children", Cochrane Database Syst Rev, 1/4, 2016.

Yıldırım, Uğur ve Ender Seçkin. "Evaluating of the Patients with Isolated Nasal Fracture Which Had Been Refered to Erzincan Training And Research Hospital”, Arch Basic Clin Res, 2/1, (2020): 11-14.

Yiğit, Ayhan, Gözlük Kırmızıŏlu Pınar ve Yavuz Alper Yener. "Nif (Olympos) Dağ Kazısı", XXIII. Arkeometri Sonuçları Toplantısı, 111-126. Kocaeli: T C Kültür ve Turizm Bakanlığg Kültür Varlıkları ve Müzeler Genel Müdürlüğü Yayınları, 2007.

Yücetaş Şeyho Cem, Kadir Oktay, Tayfun Çakır ve Erman Tahsin. "Torakal (T3T10) Vertebra Kırıklarına Yaklaşım”, Türk Nöroşirurji Dergisi, 30/3, (2020): 418-427.

Ziroğlu, Nezih ve Huri, Gazi. "Femur Şaft Kaynamama", TOTBİD (Türk Ortopedi ve Travmatoloji Birliği Derneği) Dergisi, 16, (2017): 568-572. 